
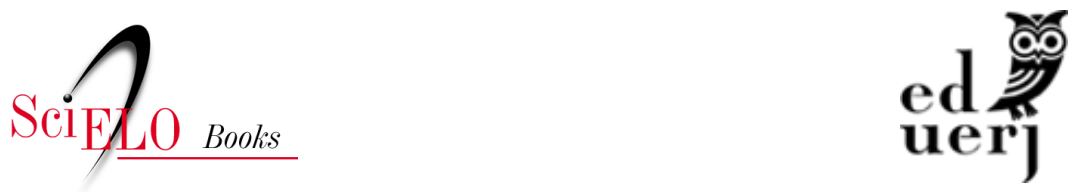

\title{
2. Política externa brasileira, modelo de desenvolvimento e coalizões políticas
}

\author{
Tiago Nery
}

\section{SciELO Books / SciELO Livros / SciELO Libros}

NERY, T. Política externa brasileira, modelo de desenvolvimento e coalizões políticas. In: A política externa brasileira e a UNASUL: geopolítica e expansão do capitalismo brasileiro na América do Sul [online]. Rio de Janeiro: EDUERJ, 2021, pp. 109-195. Sociedade e política collection. ISBN: 978-65-87949-19-2. https://doi.org/10.7476/9786587949192.0004.

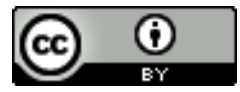

All the contents of this work, except where otherwise noted, is licensed under a Creative Commons Attribution 4.0 International license.

Todo o conteúdo deste trabalho, exceto quando houver ressalva, é publicado sob a licença Creative Commons Atribição 4.0.

Todo el contenido de esta obra, excepto donde se indique lo contrario, está bajo licencia de la licencia Creative Commons Reconocimento 4.0. 


\section{Política externa brasileira, modelo de DESENVOLVIMENTO E COALIZÕES POLÍTICAS}

Este capítulo analisa as relações entre a política externa brasileira, o modelo de desenvolvimento econômico e as coalizões políticas entre o período nacional-desenvolvimentista e o primeiro governo Dilma. Na primeira seção, observa-se certa continuidade da política externa brasileira entre 1930 e 1989, quando houve um consenso em torno do projeto de industrialização. As seções seguintes analisam um momento marcado pela crise do nacional-desenvolvimentismo e dos paradigmas diplomáticos, o americanismo e o globalismo. A partir da década de 1990, com a redemocratização e o colapso do consenso industrializante, observa-se uma preponderância da dimensão conjuntural e de aspectos político-ideológicos na política externa brasileira. O ciclo eleitoral, assim, passa a influenciar a discussão sobre política exterior. Ademais, o papel dos presidentes e a visão de mundo dos partidos políticos passam a desempenhar um papel mais relevante na definição da política externa brasileira.

A primeira seção trata das relações entre política externa brasileira e modelo de desenvolvimento, destacando-se a influência de duas ideias-chave - autonomia e desenvolvimento -, na política exterior durante o período nacional-desenvolvimentista. Nessa época, a política externa converteu-se em vetor do modelo de industrialização por substituição de importações. A crise do projeto de desenvolvimento coincidiu com o ocaso dos paradigmas da diplomacia brasileira. Assim como nos anos 1930, na década de 1990 o Brasil atravessou uma conjuntura crítica que se caracteriza 
por uma combinação de transformações sistêmicas e domésticas. A hegemonia das ideias neoliberais, no plano internacional, levou ao fim do consenso desenvolvimentista em setores das elites econômica e burocrática do país.

Na segunda seção, são analisadas as propostas de política externa dos partidos políticos brasileiros, com destaque para a polarização envolvendo o PSDB e o PT. Após uma breve discussão da literatura sobre a temática, realiza-se uma comparação entre as propostas de política externa dos dois partidos, por meio do levantamento de todos os programas de governo (dados primários) apresentados entre 1994 e 2014.

$\mathrm{Na}$ terceira seção, analisa-se o governo Fernando Henrique Cardoso (1995-2002), destacando-se as reformas econômicas realizadas e a política externa adotada. $\mathrm{O}$ ex-presidente liderou uma coalizão política hegemonizada pelos interesses rentistas que logrou a estabilização monetária. Nesse período, a política externa tornou-se subsidiária à estabilidade macroeconômica, com o objetivo de garantir a credibilidade por meio da modernização econômica e da adesão do país aos regimes internacionais.

$\mathrm{Na}$ quarta seção, são analisados os dois governos de Lula (2003-10) e o primeiro mandato de Dilma (2011-14). O ex-presidente liderou uma coalizão política heterogênea, envolvendo o subproletariado, os trabalhadores organizados e alguns setores da grande burguesia nacional. Já Dilma assumiu em um momento de crise internacional, seu governo alcançou menor crescimento e enfrentou maior conflito distributivo. Os governos do PT assumiram uma diplomacia dotada de um revisionismo moderado e reincorporaram metas de desenvolvimento à política externa, que passou a priorizar parcerias estratégicas com os países do Sul. No plano mundial, a diplomacia brasileira teve papel destacado na criação de coalizões de geometria variável. Na esfera regional, o governo brasileiro priorizou a América do Sul, com o adensamento institucional do Mercosul e a criação da Unasul, que tende a projetar geo- 
politicamente a região. $\mathrm{O}$ capítulo termina com uma breve síntese das principais temáticas tratadas ao longo das seções.

\subsection{As relações entre política externa, autonomia e modelo de desenvolvimento no Brasil}

A trajetória da política externa brasileira indica que existe uma vinculação entre o modelo de desenvolvimento econômico e a maneira que o país se insere no sistema internacional. Entre 1930 e 1980, durante a vigência do nacional-desenvolvimentismo, a busca do desenvolvimento tornou-se o principal vetor da política exterior. Todavia, nos anos 1990, as mudanças no contexto internacional e o esgotamento do projeto desenvolvimentista geraram uma crise de paradigma na política externa. Nesse sentido, a hegemonia neoliberal e a vitória de uma coalizão política liberal-conservadora alteraram significativamente a forma de inserção do Brasil no mundo.

Historicamente, duas ideias-força ajudam a explicar, juntamente com a memória institucional de sua principal agência burocrática - o Itamaraty -, os principais traços de continuidade da política externa brasileira. A primeira é a ideia de autonomia, que fez com que, ao longo do século XX, a política exterior fosse marcada pela busca de recursos de poder que garantissem mais autonomia ao país no plano mundial, mesmo quando essa estratégia envolvia o alinhamento com determinada potência. A segunda é a busca do desenvolvimento econômico, que significou o empenho em identificar os recursos externos que, em diferentes conjunturas internacionais, pudessem ser mobilizados para atender ao imperativo interno do desenvolvimento. Durante o período nacional-desenvolvimentista, essas duas linhas mestras se traduziram em identificar as modalidades possíveis de uma integração controlada na economia mundial, mobilizando recursos para aprofundar a industrialização e o desenvolvimento. Traduziu-se também num esforço de construir o espaço da autonomia nacional, por meio de um relativo distan- 
ciamento em relação aos polos de poder do sistema internacional (Lafer, 2004; Pinheiro, 2000, 2004).

Gelson Fonseca Jr. (2004), primeiramente, e Tullo Vigevani e Gabriel Cepaluni (2011), posteriormente, elaboraram uma tipologia sobre as variações do conceito de autonomia, visto como um elemento constante na política externa brasileira. No século XX, segundo esses autores, o Brasil adotou três estratégias para alcançar a autonomia: a distância, a participação e a diversificação. A autonomia pela distância consistiu em uma política externa de não alinhamento automático a regimes internacionais, e foi adotada entre 1960 e 1989; a segunda, pela participação, predominou nos anos 1990 e foi marcada pela tentativa de influenciar a formulação das regras do sistema internacional; por fim, a autonomia pela diversificação, adotada no governo Lula, significou uma política externa caracterizada pela ênfase nas relações Sul-Sul e pela crítica às assimetrias da ordem internacional.

No entanto, a tese segundo a qual a busca da autonomia constitui um traço perene da política externa brasileira deve ser criticada. Tal hipótese se apoia no falso pressuposto de que sempre houve consenso nacional sobre a inserção do Brasil no mundo. Por ser essencialmente político, o conceito de autonomia está relacionado com a ideologia predominante nas coalizões políticas domésticas. Entre 1930 e 1989, houve consenso apenas em relação aos aspectos econômico-comerciais do modelo de desenvolvimento, o que não ocorreu em relação à dimensão política e ao significado do conceito de autonomia. Assim, por exemplo, durante a Política Externa Independente (PEI), a diplomacia brasileira procurou garantir a soberania do país e, internamente, melhorar as condições de vida da classe trabalhadora, que, então, integrava a coalizão desenvolvimentista no poder. $\mathrm{O}$ mesmo não pode ser dito dos objetivos da política externa do regime militar, que apoiou um projeto de modernização excludente. 
A partir dos anos 1990, com a crise do projeto de industrialização, a falta de consenso que havia em relação à ideia de autonomia se estendeu ao modelo de desenvolvimento. Os conflitos político-ideológicos atingiram a política externa, refletindo a ausência de um consenso nacional sobre um novo modelo de desenvolvimento econômico. Nesse sentido, há diferenças entre o desejo de inserção global contido na política externa do governo Fernando Henrique e a proposta de uma integração autonômica e, por vezes, contra-hegemônica, da política externa do governo Lula. Desse modo, Marco Aurélio Garcia (2014, p. 98) tem razão quando afirma: "é bom eliminar assim a ideia falsa de que a política externa não divide. Ela pode dividir, sim, e é bom que assim o seja, como ocorre nas democracias".

A ideologia da autonomia e do desenvolvimento enfatizava tanto a economia capitalista mundial, que conteria mais restrições do que oportunidades, quanto o sistema político internacional, no qual a hegemonia dos Estados Unidos era vista como um obstáculo à conquista do desenvolvimento brasileiro e à sua capacidade de alcançar melhores posições na hierarquia do poder internacional. A partir da década de 1950, quando os fundamentos do projeto desenvolvimentista ganharam contornos mais nítidos, setores da elite e da sociedade passaram a defender que a política externa apoiasse o esforço de desenvolvimento. Disso resultou um nacionalismo integrador do espaço nacional, visto como um meio para atingir um fim: o desenvolvimento (Cervo, 2003; Hurrell, 2009b; Lafer, 2004).

Alguns analistas observam que o Brasil sempre adotou concepções e práticas próprias em relação ao conceito de autonomia decisória. De fato, os fatores econômicos e estratégicos tiveram, ao longo da história, mais peso na ideia autonomista do que os regimes políticos. Ademais, a autonomia raramente levou a "escolhas dramáticas" ou conflitos abertos, salvo, talvez, nos foros multilaterais econômicos, onde o impacto do conflito é normalmente atenuado. Esse sentido pragmático do uso do conceito de autonomia difere de 
sua utilização pelos demais países latino-americanos que soem oscilar entre relações de integração assimétrica, como no caso do México, ou de confrontação antagônica, como a Venezuela bolivariana. No caso do Brasil, os espaços de autonomia costumam ser abertos de maneira a evitar o confronto, fazendo com que, mesmo nos momentos de contestação, uma medida de realismo e moderação consiga evitar que as crises escapem à linguagem das variantes do ocidentalismo. Assim, em vez de uma confrontação antagônica, a política externa brasileira tem se pautado por uma confrontação autonômica, defendendo um revisionismo moderado e um regionalismo autônomo (Fonseca Jr., 2004; Guimarães, 2008; Saraiva, 2014). ${ }^{1}$

Em relação ao conceito de autonomia, Gerson Moura analisou as possibilidades de um país dependente exercer uma política externa autônoma. Segundo Moura (2012), isso depende tanto da situação internacional quanto do equilíbrio político interno. $\mathrm{O}$ primeiro fator está relacionado ao grau de abertura da situação internacional ou ao grau de consolidação do sistema de poder. Durante o processo de abertura relativa dos anos 1930, o Brasil realizou o jogo da equidistância ou do equilíbrio pragmático em face das grandes potências, o que foi possível até o início da guerra, que pôs fim a esse jogo e forçou os políticos brasileiros a definir suas posições com clareza. Em relação à segunda condição, o equilíbrio político interno pode levar o aliado subordinado tanto a se acomodar pas-

1 O temor a determinadas configurações sociais reformistas do republicanismo e do jacobinismo hispano-americanos, além da oposição às tendências integradoras de orientação bolivariana, fizeram muitas vezes a diplomacia brasileira se associar às grandes potências como contraponto aos países vizinhos. Essa atitude costuma levar o Brasil a se considerar um "país diferente" do restante da América Latina (Visentini, 2013). A visão do Brasil como um país distinto das demais nações sul-americanas existe desde o século XIX. No ensaio Balmaceda, sobre a guerra civil chilena que levou ao suicídio o presidente José Manuel Balmaceda, Joaquim Nabuco (2008, p. 33) destacou que Brasil e Chile constituíam exceções genuínas na América do Sul, "saliências de terra firme entre ondas revoltas e ensanguentadas". Em sua visão, ambos teriam Estados mais consolidados e sociedades mais estáveis, sem as rupturas frequentes dos outros países da região. 
sivamente ao sistema de poder da grande potência quanto a buscar ativamente a ampliação de sua margem de manobra ou de seu poder de barganha. A direção da política interna depende não apenas dos interesses do Estado, mas também da maneira como as diferentes classes sociais se relacionam com a política externa e como atuam para alcançar seus objetivos. Por fim, outro fator que entra em cena é a forma como os valores dos países centrais são assimilados e traduzidos no contexto nacional: quanto maior o grau de assimilação, menor a capacidade de ação autônoma por parte do país periférico.

O principal fator que explica a continuidade, as mudanças e as rupturas da política externa brasileira é o modelo de desenvolvimento nacional, e não o regime político. De fato, não há uma relação causal necessária entre regime político e política externa, pois uma mudança na natureza do primeiro não determina uma alteração no conteúdo da última. Portanto, a política externa pode ser alvo de uma revisão profunda sem que ocorra alteração do regime político. Durante o nacional-desenvolvimentismo, a política exterior converteu-se em instrumento de apoio ao projeto de industrialização, tanto nos governos democráticos quanto nos autoritários. No entanto, deve-se chamar a atenção para o fato de que a implantação de um mesmo modelo de desenvolvimento não implica a adoção de uma única linha de política externa (Bernal-Meza, 2003; Cervo, 2003; Pinheiro, 2004).

No século XX, a política externa brasileira pode ser analisada a partir do que se identificou como seus paradigmas diplomáticos. Estes representam teorias de ação diplomática, constituídas por distintas visões da natureza do sistema internacional por parte dos formuladores de política de cada época. Tal conjunto mais ou menos articulado de ideias ou visões pode ou não estar respaldado por teorias já existentes. A adoção de um paradigma implica diferentes cursos de ação, o que torna os paradigmas relativamente excludentes entre si e passíveis de substituição. Assim, desde a gestão do Barão de Rio Branco, entre 1902 e 1912, até o início dos anos 1990, a 
política externa teria oscilado entre o americanismo e o globalismo, quando então teria iniciado um novo tempo na política e economia nacionais responsável pela crise final de ambos (Lima, 1994; Pinheiro, 2000).

De acordo com o americanismo, os Estados Unidos eram vistos como uma potência global e hegemônica no hemisfério ocidental, o que convertia aquela nação em eixo da política exterior do Brasil. Em função da coalizão política dominante, esse paradigma ora enfatizava a convergência ideológica, ora destacava os vínculos pragmáticos entre as duas nações como meio para aumentar o poder de negociação do país. A partir dos anos 1960, a crescente complexificação da sociedade brasileira e as mudanças no contexto internacional levaram ao advento do globalismo, concebido como uma alternativa ao americanismo. $\mathrm{O}$ novo paradigma elegia a diversificação das relações exteriores como condição para o aumento do poder de barganha do país no sistema internacional (Lima, 1994; Pinheiro, 2000).

Segundo Letícia Pinheiro (2000), a política externa brasileira pode ser dividida em quatro grandes momentos, correspondendo aos períodos de hegemonia de cada um desses paradigmas. Do início do século XX até o final dos anos 1950, e novamente entre 1964 e 1974, o americanismo foi o paradigma dominante. Já o globalismo surgiu nos anos da PEI, entre 1961 e 1964, sofreu um breve interregno após o golpe cívico-militar e foi retomado pelo governo Geisel, em 1974, perdurando até o final da década de 1980, quando chegou ao seu limite.

De acordo com Maria Regina Soares de Lima (1994, p. 35), o paradigma globalista é caracterizado por sua essência plural e possui diversas influências intelectuais, entre as quais se destacam: a) a crítica nacionalista da matriz americanista da política externa brasileira gerada no interior do Instituto Superior de Estudos Brasileiros (ISEB); b) a visão cepalina das relações assimétricas centro-periferia que permitiu a construção de uma identidade econômica dos paí- 
ses latino-americanos, possibilitando a atuação deles como atores coletivos no plano internacional; e c) o pensamento realista das relações internacionais, particularmente a concepção do sistema internacional como anárquico, onde prevaleceria o princípio da autoajuda na ação dos atores estatais.

O novo paradigma possibilitou uma redefinição da identidade da política externa brasileira tanto no plano político quanto no âmbito econômico. Com a PEI e, posteriormente, com o Pragmatismo Responsável, o Brasil transitou dos modelos "ocidental puro" - do governo Dutra (1946-50) - e "ocidental qualificado" - do segundo governo Vargas (1951-54) e da administração Kubitschek (1956-61) - para um modelo "ocidental autônomo". Isso significou a possibilidade de criar, no marco do Ocidente, uma identidade própria, sem alinhamento com as doutrinas e posições da liderança do bloco. Assim, a política externa brasileira passou a adotar perspectivas próprias em diversos temas, como, por exemplo, desarmamento e economia internacional. $\mathrm{Na}$ esfera econômica, as ideias da CEPAL contribuíram para fornecer uma identidade específica para os países em desenvolvimento, apesar de suas diferenças nacionais em termos de localização geográfica, sistema econômico e regime político. A teoria estruturalista e a emergência do eixo Norte-Sul possibilitaram ao MRE encontrar na diplomacia econômica multilateral uma oportunidade para complementar as políticas governamentais de desenvolvimento industrial. Além disso, o Brasil contribuiu para a articulação diplomática dos países em desenvolvimento no G-77 e a transformação de propostas em ação política na UNCTAD (Fonseca Jr., 2004; Lima, 1994).

O fato de ser ocidental no campo dos valores, em virtude de sua formação histórica, não impediu que o Brasil se inserisse entre as nações do Terceiro Mundo com as quais tinha posições afins no quadro das ações específicas voltadas para o desenvolvimento, que respondiam ao interesse nacional. Disso resulta a ideia da "dupla inserção", que representa a especificidade de pertencer a um "outro 
Ocidente". Trata-se de uma especificidade compartilhada com parte da América Latina no âmbito do Terceiro Mundo, que também abrange, na sua diversidade, países africanos e asiáticos, cujas trajetórias e matrizes culturais e demográficas diferem da brasileira. Essa é uma das razões que explicam por que o Brasil integrou o G-77, com o qual compartilhava os desafios de superar a pobreza e o subdesenvolvimento, mas foi apenas um observador do Movimento Não Alinhado (MNA). Além de seus contornos afro-asiáticos, o caráter de confrontação do MNA poderia impor constrangimentos à diplomacia brasileira (Fonseca Jr., 2004; Lafer, 2004). Isso porque, enquanto o G-77 estava integrado à ONU, o MNA desafiava a bipolaridade e as áreas de influência dos Estados Unidos e da então União Soviética.

As ideias-chave de autonomia e desenvolvimento e os paradigmas de política externa possuem uma íntima conexão com os processos políticos, econômicos e sociais que ocorreram durante sessenta anos no Brasil. A sociedade brasileira mudou significativamente a partir de 1930, em função do conjunto de políticas públicas, inclusive a externa, que foram inspiradas por um nacionalismo econômico. Tal nacionalismo foi consequência da tensão gerada pelo desenvolvimento desigual em uma economia mundial unificada, sendo, portanto, uma reação ao atraso econômico. Nesse sentido, o projeto nacional-desenvolvimentista moldou a modernização acelerada do país até a década de 1980. Desencadeado e dirigido pelo Estado, aquele projeto pretendia alcançar não apenas a estrutura produtiva nacional, mas também a criação de instituições adequadas à modernidade, uma modernidade conservadora, mas com reflexos na cultura e na vida cotidiana da sociedade.

O nacionalismo econômico teve suas origens no período 19301945, quando ocorreu uma primeira e limitada tomada de consciência da problemática da industrialização por parte de uma nova elite técnica, civil e militar, que naquele momento se instalava nas instituições estatais implantadas após a Revolução de 1930. No entanto, 
o desenvolvimentismo, ou seja, a ideologia de superação do subdesenvolvimento nacional com base na acumulação de capital na indústria, somente se tornaria hegemônico na segunda metade dos anos 1950 . O desenvolvimentismo era uma estratégia nacional de desenvolvimento que se apoiava na então recente economia do desenvolvimento, com influências da economia política clássica, do nacionalismo econômico alemão, do marxismo, da teoria macroeconômica keynesiana e da teoria estruturalista latino-americana. Tratava-se de um projeto de desenvolvimento acelerado, cuja liderança coube a uma coalizão de classes que envolvia os empresários industriais, a tecnoburocracia pública e privada e os trabalhadores urbanos (Bielschowsky, 2000; Bresser-Pereira, 2009; Nery, 2011).

O economista Wilson Cano (2014, p. 3) tem razão quando afirma que "não há, na história, país algum que se desenvolveu, prescindindo de uma generalizada industrialização e de um forte e ativo papel do Estado nacional". Fora do Ocidente, o primeiro processo bem-sucedido de catch up ou "alcançamento" foi a Restauração Meiji no Japão, em 1868. Posteriormente, outros países periféricos retardatários lograram se industrializar, como China, Coreia do Sul, Índia e Turquia. Na América Latina, apenas Argentina, Brasil e México conseguiram instalar um parque industrial e, destes, somente o Brasil avançou na montagem mais expressiva, conquanto parcial, do setor de bens de capital. Entre 1947 e 1980, o crescimento médio da economia brasileira foi acima de $7 \%$ ao ano. Em poucas décadas, o Brasil conseguiu transformar sua economia primário-exportadora, inaugurando, por assim dizer, sua "maioridade econômica" com o chamado modelo de industrialização por substituição de importações, o que permitiu o deslocamento do centro dinâmico para dentro do país (Bresser-Pereira, 2013; Cano, 2014; Cardoso, 2010; Paulani, 2008).

Apesar de não ser uma instituição criada pelo modelo de desenvolvimento com base na industrialização por substituição de importações, o papel do Itamaraty foi central à consolidação doméstica do 
modelo e ao seu reconhecimento internacional. De acordo com Maria Regina Soares de Lima e Monica Hirst (2009, p. 48),

Uma ligação estreita e virtuosa foi estabelecida entre os objetivos da ISI e o objetivo de construção de uma política externa autônoma. Isto teve duas consequências. Primeiro, o Itamaraty obteve considerável legitimidade doméstica por seu papel como um dos principais instrumentos de desenvolvimento do país. Segundo, o Itamaraty adquiriu poderosa 'memória institucional' na qual muitas das características e valores associados ao ISI retiveram influência e atratividade, mesmo após o declínio desse modelo de desenvolvimento.

A postura de converter a política externa em instrumento do modelo de industrialização por substituição de importações foi esboçada pelos governos dos anos 1950. Nesse sentido, a Operação Pan-Americana (OPA) foi uma inovadora afirmação da diplomacia presidencial, por meio da qual Juscelino Kubitschek articulou, no âmbito do sistema interamericano, o imperativo do desenvolvimento como condição de manutenção da democracia e da paz. Ao levantar problemas novos e ensaiar a multilateralização da política externa brasileira, a OPA aprofundou a visão sobre os problemas econômicos do desenvolvimento, contribuindo para a criação do Banco Interamericano de Desenvolvimento (BID), em 1959 (Lafer, 2004; Visentini, 2013).

Entre 1950 e 1970, consolidou-se o chamado tripé do modelo de desenvolvimento, em torno do qual se articulavam a economia do setor público, as empresas monopolistas internacionais e o setor capitalista moderno local. Enquanto o Estado se encarregou do núcleo básico da indústria pesada (energia, petróleo, siderurgia), as corporações transnacionais responsabilizaram-se pelos bens duráveis, com destaque para o setor automobilístico, cuja produção se destinava às classes média e alta. Segundo a política de substitui- 
ção de importações, as áreas consideradas estratégicas deveriam ser estimuladas e protegidas da competição de produtos importados por meio de barreiras tarifárias e generosos subsídios estatais. Em termos econômicos, isso significava entregar o mercado interno em troca de capital externo, facilitando a instalação no país de empresas transnacionais que trariam capitais em troca do acesso privilegiado à economia doméstica (Domingues, 2009; Goldenstein, 1994; Nobre, 2013; Paulani, 2008).

Nos anos 1960, as transformações na economia brasileira e no sistema internacional demandavam mudanças na política externa. Nesse contexto, a PEI possibilitou ao Brasil transitar de uma diplomacia voltada ao subsistema regional para uma realmente mundial. A diversificação dos relacionamentos objetivava ampliar os espaços de autonomia, levando à aproximação com os países africanos e asiáticos na esteira dos processos de descolonização, além do restabelecimento das relações diplomáticas com o campo socialista. Após o golpe militar de 1964, ocorreu uma tentativa de retorno ao americanismo por meio de uma política externa baseada no princípio de fronteiras ideológicas. A partir de 1967, no entanto, a diplomacia voltou a enfatizar os objetivos de autonomia e desenvolvimento. O novo regime não desconhecia o conflito Leste-Oeste, sobretudo na esfera regional, mas priorizava o eixo Norte-Sul no plano multilateral, como forma de alcançar suas metas de desenvolvimento econômico (Lafer, 2004; Pinheiro, 2004; Visentini, 2013).

Os argumentos e as proposições diplomáticas da PEI e do Pragmatismo Responsável eram afins, mas não idênticos, pois os contextos interno e externo tinham mudado. As duas linhas diplomáticas constituem momentos de ruptura na história da política externa. No entanto, o hiato entre ambas somente seria fechado quando o Pragmatismo Responsável retomou alguns conceitos centrais à PEI. O Brasil do governo Ernesto Geisel (1974-79) tinha uma economia mais desenvolvida e complexa, fazendo com que a universalização das interações diplomáticas fosse um dos principais 
objetivos do Pragmatismo Responsável. Paralelamente a uma atitude crítica em relação às grandes potências, o chanceler Azeredo da Silveira implementou uma importante política africana, além de ter realizado uma expressiva aproximação com o mundo árabe, ditada, acima de tudo, pela crise do petróleo. Cumpre destacar igualmente o significado do estabelecimento de relações diplomáticas com a China, em 1974. A fim de preservar os espaços de autonomia, a diplomacia brasileira diversificou os contatos com o mundo desenvolvido, cujo exemplo mais marcante foi a assinatura do acordo nuclear com a Alemanha Ocidental, em 1975. Não pode deixar de ser mencionado o estremecimento das relações com os Estados Unidos, que resultou na denúncia, em 1977, do acordo militar vigente desde 1952 . O conjunto dessas medidas contribuiu para redefinir as premissas de inserção do país na ordem mundial. Na busca de autonomia e universalismo, o Brasil flexibilizou os condicionamentos ideológicos impostos pela Guerra Fria e passou a se identificar com as demandas do Terceiro Mundo. Assim, as principais vulnerabilidades externas eram identificadas como sendo econômicas, e não militares (Fonseca Jr., 2004; Hirst, 2009; Lafer, 2004).

Há ainda algumas diferenças marcantes entre a PEI e o Pragmatismo Responsável que merecem ser destacadas. Para Francisco Clementino de San Tiago Dantas, ex-chanceler e um dos principais formuladores da PEI, a política externa brasileira deveria garantir a soberania do país e, no plano interno, colocar os trabalhadores no centro de sua vida social e política. Aspectos dessa política externa reapareceriam anos depois, no Pragmatismo Responsável, excluindo-se, obviamente, o seu conteúdo político e social. Como destaca Marco Aurélio Garcia (2014, p. 97), “o eufemismo da designação buscava relativizar (ou ocultar) os vínculos entre a reorientação diplomática do governo Geisel e a Política Externa Independente, ainda que a ditadura não reservasse aos trabalhadores o lugar que Santiago Dantas lhes atribuíra no começo da década dos 60 ”. 
Durante a vigência do nacional-desenvolvimentismo, as políticas comerciais estiveram subordinadas aos objetivos de política externa. Isso levou a uma visão, no campo das negociações comerciais, em que a clivagem Norte-Sul desempenhava um papel decisivo não apenas na explicação das dificuldades enfrentadas pelo Brasil para atingir suas metas econômicas, mas também na definição dos parâmetros que orientavam a formação de alianças e coalizões necessárias para alavancar os interesses do país na esfera internacional. Na época da Guerra Fria, a política externa brasileira adotou posição discreta em assuntos relativos à paz e à segurança internacional, pois a participação do país nos fóruns multilaterais era influenciada principalmente pelo objetivo de promover o desenvolvimento econômico (Lima e Hirst, 2009; Motta Veiga, 2007). Assim, havia um consenso em torno do modelo de desenvolvimento, embora não houvesse harmonia em relação à dimensão política da política exterior.

Nas negociações visando à reforma do regime de comércio e desenvolvimento criado após a Segunda Guerra Mundial, o Brasil desempenhou papel decisivo em defesa de uma nova ordem econômica internacional; ao lado de países como Índia e México, o país destacou-se na coordenação da coalizão terceiro-mundista. A atuação da delegação brasileira na II UNCTAD resultou na escolha de Azeredo da Silveira como presidente do G-77. Entre as décadas de 1960 e 1980, o Brasil não assumiu o papel de demandante no regime comercial e praticamente não negociava questões específicas. No entanto, a participação brasileira centrou-se na defesa de certos princípios, como: a) preferência por um regime comercial baseado nos princípios de cooperação e desenvolvimento, como o da UNCTAD, em oposição às ideias de livre comércio dominantes no GATT; b) apoio ao fortalecimento de normas comerciais capazes de limitar medidas arbitrárias e ações unilaterais e protecionistas de países desenvolvidos; c) apoio à implementação de regras que favorecessem países em desenvolvimento, tais como a de tratamento especial e diferenciado e a de não reciprocidade; d) alinhamento político com 
o G-77 em outras arenas multilaterais (Lima e Hirst, 2009; Motta Veiga, 2007; Visentini, 2013).

Após várias etapas do modelo de substituição de importações - a última ocorrida no governo Geisel sob o impacto do primeiro choque do petróleo -, o Brasil dispunha de uma matriz interindustrial praticamente completa. Com um atraso de quase três décadas, foram preenchidas as áreas estratégicas de insumos básicos e bens de capital, que Vargas tinha percebido como de fundamental importância para ordenar o crescimento econômico do país. Durante o II PND (1974-79), o Brasil aplicou sua versão mais avançada do projeto nacional-desenvolvimentista, aprofundando o processo substitutivo de importações, com vistas a tornar-se autossuficiente em insumos básicos e, se possível, em energia.

Na tabela 2, observa-se a transformação da estrutura produtiva brasileira nos últimos setenta anos. É possível verificar como a indústria de transformação ${ }^{2}$ cresceu entre os anos 1950 e 1980, passando a declinar desde então. A partir de meados dos anos 1990, a tendência constante de apreciação cambial continuou reduzindo a participação setorial da indústria de transformação, que representa, hoje, pouco mais de $10 \%$ do PIB.

2 O Setor Indústria é uma agregação de quatro segmentos: a) mineração; b) construção civil; c) produtor de serviços de utilidade pública (água, energia, gás); d) indústria manufatureira ou de transformação. O último segmento envolve maior complexidade tecnológica e é responsável pela promoção e disseminação de maior conteúdo de progresso técnico aos demais setores da economia (Cano, 2014). 
Tabela 2 - Brasil: distribuição percentual do PIB por setor econômico

\begin{tabular}{lccc}
\hline Período & Agropecuária & $\begin{array}{c}\text { Indústria de } \\
\text { transformação }\end{array}$ & Serviços \\
\hline $\mathbf{1 9 5 1 - 6 0}$ & 22,2 & 22,2 & 52,5 \\
$\mathbf{1 9 6 1 - 7 0}$ & 15,1 & 27,3 & 54,4 \\
$\mathbf{1 9 7 1 - 8 0}$ & 12,1 & 32,6 & 53,2 \\
$\mathbf{1 9 8 1 - 9 0}$ & 11,2 & 33,1 & 58,0 \\
$\mathbf{1 9 9 1 - 2 0 0 0}$ & 6,6 & 19,7 & 70,4 \\
$\mathbf{2 0 0 1 - 1 0}$ & 5,7 & 16,2 & 67,1 \\
$\mathbf{2 0 1 1 - 1 8}$ & 5,2 & 12,4 & 71,3 \\
\hline
\end{tabular}

Fonte: Instituto Brasileiro de Geografia e Estatística (IBGE), 2019.

A partir do lançamento do II PND em setembro de 1974, as políticas governamentais promoveram o aumento da exploração, produção e refino do petróleo, bem como a mudança estrutural da matriz energética, com um ambicioso programa de construção de hidrelétricas, usinas nucleares e produção de álcool para combustível automobilístico, o Projeto Proálcool. Na esfera tecnológica, houve o progresso dos investimentos em educação superior e seus recursos de fomento; a expansão dos centros de pesquisa e desenvolvimento tecnológico das empresas estatais; a formação de joint ventures entre empresas brasileiras e estrangeiras, sobretudo para prospecção no Oriente Médio pela Braspetro; o fortalecimento do setor de engenharia consultiva e de construção; e o forte controle sobre contratos de transferência de tecnologia, cuja orientação era aumentar a absorção tecnológica das empresas nacionais. No plano comercial, o governo aplicou uma estratégia agressiva de exportações, que passou a refletir as mudanças na estrutura produtiva. Em 1979, pela primeira vez na história econômica brasileira, a participação dos manufaturados $(43,6 \%)$ no valor total das exportações foi maior do que a parcela correspondente dos produtos básicos (43\%). O conjunto dessas medidas colocou o Brasil na posição de único país 
da América Latina dotado de um parque industrial diversificado (Gonçalves, 2013; Visentini, 2013).

A continuidade desse projeto de modernização foi solapada, em sua faceta econômica, pela abrupta interrupção da entrada de capital externo no final da década de 1970. A redução da vulnerabilidade externa do Brasil nas esferas comercial e produtiva foi neutralizada pelo aumento da vulnerabilidade externa estrutural na esfera financeira. Como os planos nacionais de desenvolvimento foram financiados por empréstimos contratados com taxas de juros flexíveis - basicamente a Libor (inglesa) e a Prime (estadunidense) -, a brutal elevação dos juros pelo Federal Reserve (Fed), na sequência do segundo choque do petróleo, bloqueou qualquer possibilidade de refinanciamento da dívida não apenas para o Brasil, mas também para o conjunto da América Latina. ${ }^{3}$ A elevação das taxas de juros por Paul Volcker, então presidente do Fed, de uma média anual de $11,2 \%$, em 1979, para 20\%, em 1981, preparou o capitalismo para ingressar em uma nova fase, marcada pela retomada da força do dólar e pelo processo de financeirização e centralização de capitais. Desde então, o dólar assumiu uma forma ainda mais poderosa do que durante a vigência dos acordos de Bretton Woods. Ademais, o dólar flutuante, sem lastro metálico, possibilitou a retomada da hegemonia dos Estados Unidos e o início da aplicação das políticas neoliberais de desregulamentação econômica e privatizações em todo o mundo (Gonçalves, 2013; Nobre, 2013; Paulani, 2008).

A crise econômica coincidiu com os estertores do regime ditatorial. Após meio século de crescimento econômico acelerado, o modelo de substituição de importações entrava em sua fase final.

3 Com o primeiro choque do petróleo, em 1973, o barril subiu de, aproximadamente, US\$ 3,00 para US\$ 12,00. Em 1979, com o segundo choque do petróleo, o barril passou a valer US\$30,00, prejudicando países como o Brasil, que havia se endividado a taxas de juros flutuantes, algumas vezes até mesmo a taxas negativas. Entre 1978 e 1983, a dívida brasileira saltou de US\$ 43 bilhões para mais de US\$ 80 bilhões (Dauster, 2013). 
No momento em que uma verdadeira revolução produtiva estava em curso no mundo, os quinze anos em que o Brasil passou enfrentando a crise da dívida condenaram o país a um atraso considerável em seu desenvolvimento. Um dos sinais do fosso que separava a lógica nacional-desenvolvimentista da nova realidade econômica mundial foi a aprovação da Lei de Informática no final de 1984, considerada o último grande suspiro da política de substituição de importações. A lei serviu de pretexto para o governo Reagan pressionar o Brasil, forçando-o a abrir seu mercado à indústria de computadores e ao setor de serviços dos Estados Unidos (Nobre, 2013; Vigevani e Cepaluni, 2011). ${ }^{4}$

O fracasso da primeira proposta para resolver o problema da dívida externa, o Plano Backer, e as crescentes dificuldades do Terceiro Mundo levaram ao abandono do diálogo Norte-Sul na Reunião de Cúpula do G-7, em 1985. Nesse contexto de grandes dificuldades, os bancos credores não dispunham de capital suficiente para suportar um default simultâneo de Brasil, México, Argentina e Venezuela. Caso esses quatro países se unissem e cessassem os pagamentos, possivelmente lograriam um tratamento menos draconiano do que a fria execução dos contratos. Apesar das tentativas de concertação, com a oferta de empréstimos-ponte de maneira individualizada, os bancos conseguiram manter os devedores divididos. Em 1987, o Brasil estava quebrado e não havia outra saída além de decretar a moratória. Entre os devedores mencionados, o país também foi o único que suspendeu o pagamento dos juros da dívida (Dauster, 2013; Visentini, 2013).

Em depoimento sobre as negociações da dívida externa, o diplomata Jorio Dauster (2013), que foi um dos principais negociadores brasileiros, relatou alguns fatos interessantes daquele período.

4 A lei foi resultado de um expressivo acordo suprapartidário, que incluiu até setores militares. Ela previa uma reserva de mercado, pelo período de oito anos, inicialmente para empresas de capital nacional, de maneira a desenvolver a indústria de microeletrônica no país (Nobre, 2013). 
Segundo Dauster, o Secretário do Tesouro estadunidense, James Baker, rechaçou a proposta original de securitização da dívida brasileira levada a ele pessoalmente pelo então Ministro da Fazenda, Luiz Carlos Bresser-Pereira. Depois desse fracasso, o Brasil adotou a estratégia mexicana de designar um negociador oficial da dívida externa sem ligações diretas com o aparato administrativo. Entre 1990 e 1991, foram tomadas, em caráter unilateral, as principais medidas que marcaram a saída da moratória e possibilitaram a assinatura do acordo dos juros atrasados. Ficou estabelecido que os bônus relativos a esses juros somente seriam efetivamente entregues aos credores quando definidos os parâmetros do pagamento do principal. Apesar da resistência dos credores, essa vinculação era a única segurança do Brasil de que o montante total dos futuros compromissos externos seria compatível com a capacidade de pagamento do país. Por fim, a Resolução 82 de 1990 do Senado Federal, que avalizava a tese da capacidade de pagamento, removeu os questionamentos à legitimidade da renegociação e aumentou consideravelmente a credibilidade do Brasil junto aos credores.

O Plano Brady endossava o princípio da redução da dívida, desde que os países devedores adotassem programas econômicos monetaristas. As duras negociações envolvendo o Brasil, de um lado, e os Estados Unidos e os bancos credores, do outro, levaram o Brasil a adotar gradualmente políticas econômicas menos desenvolvimentistas e mais liberais. Da mesma forma que outras nações endividadas, o governo brasileiro conseguiria concluir um acordo com os credores em 1994, enquadrando-se nos termos de renegociação da dívida externa pública, seja pelo Clube de Paris (dívida entre governos), seja pelo Plano Brady (dívida com bancos) (Gonçalves, 2013; Vigevani e Cepaluni, 2011).

$\mathrm{O}$ contexto interno de crise associado às pressões internacionais forçou uma inflexão na política externa comercial brasileira durante as negociações da Rodada Uruguai do GATT. Enquanto os países desenvolvidos propunham a inclusão de novos temas e 
questionavam o princípio de tratamento especial e diferenciado, o Brasil e a Índia cooperavam na coordenação de uma estratégia de limitação de danos. No entanto, a crise do G-77 e as divisões entre os países em desenvolvimento revelaram os limites dessa estratégia e das posições terceiro-mundistas. Entre 1987 e 1988, o Brasil deixou de questionar os novos temas e começou a negociá-los por meio de propostas mais específicas (Lima e Hirst, 2009; Motta Veiga, 2007; Vigevani e Cepaluni, 2011).

No âmbito político-institucional, a aprovação da Constituição de 1988 lançou as bases de um novo modelo de sociedade, no qual as questões distributivas deveriam passar para o centro da arena política como o ponto de disputa fundamental. O texto constitucional refletia as demandas longamente reprimidas por mudanças sociais e políticas, fixando o horizonte normativo que moldaria a agenda pública dos governos seguintes. A carta constitucional, entretanto, foi promulgada na contramão do contexto internacional, marcado pela crescente influência das ideias neoliberais, que se tornariam hegemônicas com a queda do Muro de Berlim e o colapso da União Soviética, visto que, sem dúvida, a existência do mundo soviético abria espaço para imaginar-se a possibilidade de uma outra forma de desenvolvimento, menos assentada no mercado e mais ancorada no Estado (Cardoso, 2010; Kauchakje, 2014; Kerstenetzky, 2014; Nobre, 2013). Com a capitulação da social-democracia europeia e o desaparecimento do campo socialista, as resistências à globalização diminuíram.

Apesar de a mudança no regime político não ter provocado uma ruptura na política externa brasileira, a transição democrática e as transformações geopolíticas causaram alterações profundas no rumo da política exterior no final do governo Sarney (1985-90). No entanto, seria exagerado afirmar que o governo Sarney foi um divisor de águas na trajetória diplomática. Na realidade, houve uma perda paulatina de legitimidade do paradigma diplomático com a fragmentação da coalizão globalista no Itamaraty, processo que 
ocorreu paralelamente à crise do modelo de desenvolvimento. No início dos anos 1990, os dois paradigmas diplomáticos entraram em uma crise sem retorno (Lima, 1994; Pinheiro, 2004; Vigevani e Cepaluni, 2011).

Ao analisar as conjunturas críticas que atingiram o Brasil, Lima e Hirst (2009) identificam duas delas ao longo do século XX: a primeira, nos anos 1930, com a crise da economia agroexportadora e o subsequente emprego do modelo de industrialização por substituição de importações; e a segunda, na década de 1990, com o esgotamento do modelo substitutivo e o advento de uma lógica de integração competitiva à economia global. Ambas provocaram rearticulações que envolveram as dimensões doméstica e internacional.

Apesar de o sistema internacional influenciar a política doméstica e de a economia internacional pressionar os atores nacionais, os Estados têm alguma margem de manobra. De acordo com Peter Gourevitch (1993), a escolha que os países fazem depende de fatores, como a economia nacional, a distribuição interna do poder e de outros que influenciam as opções, tais quais: forças sociais, instituições intermediárias ou mecanismos de representação, estrutura estatal e ideologia. Isso significa que o sistema pode ser internacional, mas no âmbito da política nacional o efeito do sistema se sente por meio dos atores que operam dentro de cada país.

As crises são momentos não apenas de perigo, mas também de oportunidade. Segundo Gourevitch (1993), as ideologias econômicas possuem considerável significado político, pois traçam o mapa dos objetivos e requerimentos políticos, das alianças e coalizões políticas. No caso brasileiro, a crise de 1929 permitiu o surgimento de uma coalizão que passou a defender a industrialização do país. Apesar da oposição sofrida pelas forças liberais e dos conflitos no interior da coalizão, o consenso em torno do desenvolvimento industrial perdurou por quase sessenta anos. Nos anos 1990, o avanço do neoliberalismo e a crise do modelo de desenvolvimento provocaram o fim da coalizão nacional que havia defendido o projeto de industrialização. A partir 
de então, as elites industriais aderiram, com diferentes graus de entusiasmo, às políticas neoliberais hegemônicas. ${ }^{5}$

As profundas transformações geoestratégicas impactaram decisivamente os recursos de poder e a capacidade de persuasão das coalizões do Sul, com efeitos inclusive no campo dos valores. Dessa forma, o novo contexto revelou os reais limites do discurso autonomista. A razão dos países periféricos era definida por contraste com a irracionalidade dos poderosos, que tinha expressóes claras na corrida armamentista e na resistência a reformar uma ordem econômica claramente iníqua. Com o fim da Guerra Fria e o triunfo das ideias liberais, os países em desenvolvimento se viram desafiados a redesenhar seus argumentos, a refazer seu discurso, a buscar uma ressignificação do conceito de autonomia (Fonseca Jr., 2004; Lima, 1994).

A eleição de Fernando Collor interrompeu o ciclo de mobilização social que vinha desde o final dos anos 1970 e que resultou, entre outras coisas, na fundação do PT. Ao ingressar em uma pequena sigla, Collor concorreu como um outsider do sistema político, com um discurso moralista e "modernizante" que visava a superar o antigo modelo nacional-desenvolvimentista. Uma vez eleito, passou a ser voz corrente a inescapável necessidade de redu-

5 Gourevitch (1993) analisou os realinhamentos entre os grupos domésticos, que se baseiam no nexo entre o sistema internacional e as relaçốes empresariais, em cinco países (Alemanha, Estados Unidos, França, Reino Unido e Suécia), em diferentes épocas de crise (1873-96, 1929-49, 1973-86). Ele destacou dois aspectos inter-relacionados nesses realinhamentos críticos. Em primeiro lugar, a capacidade de a classe trabalhadora influenciar o debate sobre a política econômica depende da existência de profundas divergências dentro da comunidade empresarial. Em segundo, os grupos empresariais possuem diferentes "propensões marginais" a um alinhamento progressista ou conservador. Entre 1945 e 1973, os alinhamentos progressistas vincularam os empresários com a força de trabalho em torno de programas de melhores salários, de relações industriais institucionais e de sistemas de seguridade social. Todavia, as condições econômicas internacionais após 1973 solaparam esse consenso. O realinhamento conservador uniu as elites empresariais em torno de um projeto que visava a cortar custos com a força de trabalho e diminuir a rede de proteção social, projeto que persiste ainda hoje. 
zir o tamanho do Estado, privatizar empresas estatais, controlar os gastos públicos e abrir a economia. Os ganhos prometidos iam do ingresso no mundo desenvolvido à modernização do país.

Em um primeiro momento, o governo Collor (1990-92) buscou retomar o paradigma americanista como instrumento para reforçar a adoção de um novo modelo econômico ancorado na liberalização da economia, cujo eixo girava em torno da inserção competitiva do Brasil na economia mundial. No entanto, o retorno ao americanismo mostrou-se ineficaz, visto que o consenso interno em torno de uma relação especial com Washington não mais existia. O surgimento de uma ordem política constitucional e as mudanças na política econômica tiveram implicações importantes para a política externa. Uma vez que as condições internacionais não mais permitiam a volta do globalismo, era preciso encontrar uma nova estratégia. Esta pretendia associar as reformas neoliberais, no âmbito doméstico, à necessidade de adesão aos regimes internacionais com vistas a aumentar a capacidade de acesso do país a recursos financeiros e tecnológicos (Fonseca Jr., 2004; Lima e Hirst, 2009; Pinheiro, 2000, 2004).

A partir do momento em que o governo começou a afundar em escândalos e problemas, Collor buscou ampliar sua base de apoio e convidou Celso Lafer para ocupar o posto de chanceler, em abril de 1992. Desse modo, o MRE recuperou em parte sua proeminência na formulação da política externa. Lafer procurou tratar de maneira diferente - pela participação e não pela distância - os temas globais que se inseriram na agenda pós-Guerra Fria, como meio ambiente, direitos humanos, desarmamento e não proliferação nuclear. A Conferência das Nações Unidas sobre Meio Ambiente, realizada no Rio de Janeiro, em 1992, demonstrou que o país buscava maior participação internacional. No plano regional, a concepção do Mercosul como plataforma de inserção mundial convergia com o lema do governo Collor sobre a inserção competitiva do país na economia 
mundial (Lafer, 2004; Pinheiro, 2004; Vigevani e Cepaluni, 2011; Visentini, 2013).

$\mathrm{Na}$ esfera econômica, a liberalização comercial, iniciada em 1988, foi aprofundada e concluída até o final de 1993, eliminando ampla gama de barreiras não tarifárias fronteiriças e reduzindo as tarifas médias, que eram superiores a 32\% no início de 1990, para algo em torno de $13 \%$ três anos depois. Já a tarifa brasileira máxima passou de 105\%, em 1988, para 35\%, em 1993. A liberalização também aboliu os controles estatais no comércio de trigo, café e açúcar, além da proteção não tarifária aos produtos eletrônicos. A abertura gerou intensa pressão competitiva, e a indústria respondeu com novos métodos de produção e a introdução de tecnologias poupadoras de mão de obra, elevando a produtividade ao custo do crescimento das taxas de desemprego. A ruptura com o modelo nacional-desenvolvimentista também envolveu a privatização de empresas estatais. Com a criação do Programa Nacional de Desestatização em 1990, foram privatizadas 18 empresas estatais no governo Collor e 11 no governo Itamar Franco. No entanto, a intensificação do processo somente ocorreria no governo Fernando Henrique (Cardoso, 2010; Gonçalves, 2013; Motta Veiga, 2007; Vigevani e Cepaluni, 2011).

Em 1992, a diretoria da área externa do Banco Central, em meio às negociações para internacionalizar o mercado brasileiro de títulos públicos e securitizar a dívida externa, encarregou-se também de promover a desregulamentação do mercado financeiro brasileiro e a abertura do fluxo internacional de capitais. Alterando um expediente criado por uma lei de 1962, as chamadas contas CC5, o Banco Central abriu a possibilidade de qualquer agente, fosse ou não residente, enviar de forma livre recursos ao exterior, bastando, para tanto, depositar moeda doméstica na conta de uma instituição financeira não residente. Tais mudanças produziram a forma e a substância da inserção do Brasil nas finanças internacionalizadas. Dessa maneira, a liberalização financeira garantiu o livre trânsito 
dos capitais internacionais, que foram autorizados a maximizar o aproveitamento das políticas monetárias e restritivas e de juros reais elevados (Paulani, 2008, 2010). ${ }^{6}$

No âmbito político-institucional, a crise socioeconômica, as denúncias de corrupção e a falta de apoio político e social levaram ao impeachment de Collor, em 1992. Segundo Marcos Nobre (2013), teria surgido aí a segunda figura daquilo que ele chamou de "pemedebismo". Trata-se de uma cultura política dotada de mecanismos de administração de conflitos que se caracteriza por um sistema de vetos capaz de travar mudanças profundas. Sua primeira figura teria surgido durante a Constituinte sob o comando do chamado "centrão", bloco suprapartidário que conseguiu blindar o sistema político contra as forças sociais de transformação. Com o impeachment, ter-se-ia estabelecido a crença indiscutível de que Collor caíra porque não dispunha de apoio político suficiente no Congresso, pois lhe havia faltado "governabilidade". Nesse momento, surge a exigência de que esmagadoras maiorias suprapartidárias são indispensáveis para governar. Assim, a ideologia da necessidade de uma supermaioria parlamentar é a figura do "pemedebismo" tal como se espalhou pelo sistema político da década de 1990 em diante.

No breve governo de Itamar Franco (1992-94), o entusiasmo do discurso oficial com a globalização tornou-se inexpressivo. Durante a primeira passagem de Celso Amorim pelo Itamaraty, ocorreu um maior interesse pela diversificação das parcerias internacionais, antecipando algumas tendências que seriam aprofundadas no governo Lula. Com

\footnotetext{
6 As alterações nas contas CC5, realizadas por uma carta circular do Banco Central, foram feitas de modo irregular, pois uma lei federal não poderia ser regulamentada por ato e órgão de hierarquia constitucional inferior. Uma carta circular é documento que tem o papel exclusivo e restrito de "esclarecer" normas e regulamentos editados pelo Conselho Monetário Nacional. Em outras palavras, o Congresso Nacional teria de ser ouvido sobre a matéria, e não foi. A decretação da liberdade de enviar recursos para o exterior gerou uma mudança tão radical que o mercado permaneceu incrédulo, até que, em novembro de 1993, na gestão de Gustavo Franco na área externa do banco, foi publicada uma "cartilha" escancarando para os agentes econômicos aquilo que eles estavam vendo sem acreditar (Paulani, 2008, 2010).
} 
esse intuito, reforçou-se a identidade do Brasil como nação continental, com interesses múltiplos na economia mundial, e como um ator destacado no processo de regionalização. Nesse período, o Mercosul foi considerado estratégico para barrar a ofensiva dos Estados Unidos para a constituição da Área de Livre Comércio das Américas (Alca). Assim, procurou-se resgatar alguns temas tradicionais da política externa, recolocando-se o tema da autonomia (Hirst, 2009; Vigevani e Cepaluni, 2011; Visentini, 2013).

Em síntese, nesta seção procurou-se destacar as relações entre o modelo de desenvolvimento e a política externa brasileira. Com o processo de industrialização, a política exterior se converteu em instrumento central do modelo nacional-desenvolvimentista, em suas fases democrática e autoritária. A redemocratização coincidiu com a crise terminal do modelo desenvolvimentista, impactando os dois paradigmas de política externa predominantes desde o início do século XX. Os governos Collor e Itamar foram caracterizados pela brevidade de seus mandatos e não conseguiram implementar uma política externa clara e coerente, além de terem enfrentado forte instabilidade econômica e institucional. Nas próximas seções, serão analisados os governos Fernando Henrique e Lula, destacando-se o impacto das políticas econômicas e das coalizões políticas na formulação da política externa brasileira. Antes, porém, far-se-á uma breve análise da contribuição dos partidos políticos em temas de política externa.

\subsection{Partidos políticos e polarização ideológica na política externa brasileira}

No Brasil, há uma percepção difusa de que os partidos políticos possuem uma importância secundária nos debates sobre política externa. Isso podia ser válido no passado, porém desde a redemocratização observa-se um crescente interesse da sociedade e dos partidos por temas de política externa. Além da questão democrática, a 
globalização econômica também contribuiu para que mais pessoas se envolvessem com temas internacionais. Nos últimos anos, os assuntos referentes à política externa têm sido objeto de crescente polarização entre PSDB e PT. Esta seção discute brevemente essa temática e faz uma comparação dos programas de governo apresentados pelos dois partidos que vêm polarizando o debate presidencial nas últimas duas décadas. Para isso, são analisadas as propostas de política externa presentes nos programas partidários, fontes primárias fundamentais para a compreensão das diferentes visões de mundo dos dois partidos.

Gerson Moura (2012) conclui sua tese de doutorado afirmando que uma "distância cósmica" parecia separar a sociedade brasileira da política exterior, que seria concebida como um campo de ação exclusivo do Estado. Ele observa, todavia, que desde a década de 1940, a política externa já afetava a vida dos brasileiros, inclusive a das classes subalternas. Na mesma direção, Lima (1994, p. 31) também enfatiza os vínculos existentes entre política, partidos e política externa, ao afirmar que "nada más próximo de la fantasia clásica que la idea de que la política exterior está por encima de la política y de los partidos"?

Nos últimos anos, observa-se uma crescente diluição da diferença entre o "interno" e o "externo", levando ao questionamento das hipóteses que conferem à política externa uma esfera de autonomia em relação à política interna. Há uma politização do tema, cuja origem se encontra em processos políticos e econômicos. Por um lado, houve o aumento da demanda por participação na formulação e na execução das políticas de Estado, em geral, e da política externa, em particular, processo que foi influenciado pela onda democratizante do final dos anos 1980. Por outro, a abertura econômica introduziu questões distributivas nas negociações comerciais, envol-

N. do E.: Em tradução livre, "nada mais próximo da fantasia clássica do que a ideia de que a política externa está acima da política e dos partidos”. 
vendo perdas e ganhos em diferentes setores da sociedade. Além da ampliação dos temas, esses dois processos provocaram a entrada de uma multiplicidade de novos atores governamentais e não estatais, a exemplo de entidades subnacionais, agências burocráticas, Poder Legislativo, ONGs, movimentos sociais, sindicatos, empresários, meios de comunicação e partidos políticos. A conjunção desses fatores tem contribuído para a superação do insulamento burocrático do Itamaraty, aproximando a política externa das políticas públicas domésticas (Lafer, 2004; Lima, 2000; Milani, 2012).

A revalorização da temática externa pode ser creditada, em parte, aos avanços sociais e políticos consagrados na Constituição de 1988. A nova ordem constitucional procurou não apenas reequilibrar as responsabilidades dos diversos poderes na condução e no controle da política externa governamental, como também introduziu os princípios que devem nortear a ação do Estado na política internacional, conforme inscrito no art. $4 .^{\circ}$ do Título I. ${ }^{8}$ Apesar de manter quase irretocável as disposições do Executivo federal referentes às relações exteriores, a Carta Magna ampliou um pouco as prerrogativas do Poder Legislativo nessa área. Houve, portanto, uma imperceptível alteração da estrutura do poder decisório em favor de uma maior participação parlamentar na implementação da política externa, que ficou evidente, por exemplo, na prerrogativa do Senado de impor limites à aceitação de obrigações externas que acarretassem encargos financeiros ao país. Tal tendência político-institucional acabou afetando a interação dos partidos políticos

\footnotetext{
8 Art. $4 .^{\circ}$ : A República Federativa do Brasil rege-se nas suas relações internacionais pelos seguintes princípios: I - independência nacional; II - prevalência dos direitos humanos; III - autodeterminação dos povos; IV - não intervenção; V - igualdade entre os Estados; VI - defesa da paz; VII - solução pacífica dos conflitos; VIII - repúdio ao terrorismo e ao racismo; IX - cooperação entre os povos para o progresso da humanidade; X - concessão de asilo político. Parágrafo único: A República Federativa do Brasil buscará a integração econômica, política, social e cultural dos povos da América Latina, visando à formação de uma comunidade latino-americana de nações (Brasil, 1988).
} 
com a política externa, reforçando-se, desse modo, o polo partidário. Assim, a Carta de 1988 possibilitou, pela primeira vez, um maior protagonismo do Congresso e dos partidos nos assuntos relativos à política externa brasileira (Almeida, 1998; Amorim Neto, 2011; Milani, 2012).

Ao lado dos dispositivos constitucionais, outros fatores contribuíram para a politização do campo de política externa, superando a relativa indiferença da opinião pública brasileira com os assuntos internacionais, entre os quais, caberia destacar: a) a crise da dívida e os constrangimentos dela decorrentes, expressos na interferência do FMI na política econômica brasileira; b) as pressões internacionais que passaram a se fazer sentir sobre as políticas internas com o avanço das negociações da Rodada Uruguai do GATT; c) a percepção generalizada de agravamento dos problemas ambientais; d) o surgimento de iniciativas de integração regional, como o Mercosul e a Alca; e) a abertura do Itamaraty por meio de foros consultivos e da formação de delegações mistas, compostas por diplomatas e membros da sociedade civil; f) a midiatização da política externa, atraindo a atenção dos cidadãos comuns para as decisões do Estado brasileiro, envolvendo questões internacionais; g) o aumento do interesse de acadêmicos e especialistas pelo acompanhamento da política externa, além da ampliação dos cursos de graduação de relações internacionais; h) a crescente polarização partidária das agendas de política externa durante as campanhas presidenciais (Milani, 2012; Cruz, 2010).

Em relação ao aspecto ideológico, os partidos do campo da esquerda costumam conferir mais atenção às questões internacionais em seus programas do que as agremiações conservadoras. Ao analisar o quadro partidário instituído pela Constituição de 1946, Paulo Roberto de Almeida (1998) observa que quanto menor e mais estruturado ideologicamente o partido, maior atenção costumava ser dada a temas de política externa. De forma inversa, quanto maior e mais politicamente difuso o partido, a formulação dos princípios de 
política externa tornava-se menos explícita. Segundo Octavio Amorim Neto (2011), essa proposição se aplica também ao período pós-1988, embora tenha ocorrido um crescimento generalizado do interesse partidário por política externa. São os partidos de fora do campo da esquerda, sobretudo os conservadores, que relegam a política externa a um plano inferior, tanto em seus programas quanto em sua atuação no parlamento, contribuindo para o enfraquecimento do papel do Congresso na área. As agremiações conservadoras são mais dispersas do que as de centro e de esquerda, porquanto são mais personalistas, mais ligadas a redes clientelísticas e menos comprometidas com organizações e programas formais. Nesse sentido, qualquer análise do impacto de mudanças no ambiente legislativo sobre a política externa brasileira deve enfatizar as mudanças na força parlamentar dos partidos de esquerda.

No entanto, a realidade parece contestar as percepções de Almeida e Amorim Neto. Os partidos com maior atuação na área de política internacional no Brasil, PSDB e PT, não são agremiações pequenas. Enquanto o primeiro pode ser considerado atualmente de centro-direita, o segundo fez uma inflexão ao centro político desde que chegou à presidência. Ademais, o antigo Partido da Frente Liberal (PFL), atual Democratas (DEM), é um partido nitidamente de direita, mas com atuação nas comissões de relações exteriores do Congresso Nacional. Uma das razões que explicam o interesse de PSDB e PT na área de política externa pode ser atribuída ao fato de que ambos têm exercido o poder no Brasil nas últimas duas décadas.

Fundado em 1988 como uma cisão do Partido do Movimento Democrático Brasileiro (PMDB), o PSDB inicialmente se declarava como partido de centro-esquerda. Durante a discussão travada para sua criação, a ênfase na social-democracia não foi unânime, as divergências envolveram até o nome do partido. Fernando Henrique preferia Partido Popular Democrático, pois a história política brasileira discrepava muito da europeia, onde a social-democracia tinha surgido a partir do forte movimento operário, amiúde com origens 
marxistas, revolucionárias. Entre os fundadores, havia lideranças com origens na democracia-cristã, que temiam que a influência da Internacional Socialista terminasse por marcar a nascente agremiação. As questões de política externa apareceram como último item do Manifesto de fundação do partido e de maneira um tanto vaga na campanha de 1989. Isso mudaria apenas nas eleições de 1994 (Almeida, 1998; Cardoso, 2010; Mesquita, 2012b; Nobre, 2013).

Desde sua fundação em 1980, o PT demonstrou grande interesse em definir suas posições sobre os acontecimentos internacionais, em especial aqueles que afetavam os países da América Latina. Como muitos partidos de esquerda, desde seus primeiros documentos o partido defendia uma política de ativismo internacional. Muitos de seus militantes participaram de campanhas de apoio aos processos revolucionários centro-americanos e desenvolveram fortes laços de solidariedade com as vítimas das ditaduras do Cone Sul. Outras experiências relevantes na conformação da orientação internacional do PT foram o apoio à Revolução Cubana e a luta contra o apartheid sul-africano. Apesar das relações amistosas com os países da Europa Oriental, o partido não se alinhava nem ao bloco soviético, nem à social-democracia europeia. Após a queda do Muro de Berlim, o PT foi o principal mediador do Foro de São Paulo, que se constituiu em um espaço de articulação das diversas forças da esquerda latino-americana, contribuindo para o debate de ideias e a formação de uma identidade regional própria. Deve-se destacar, também, a continuidade dos trabalhos da Secretaria de Relações Internacionais (SRI) do partido, que, durante muito tempo, foi liderada pelo professor Marco Aurélio Garcia. A SRI foi responsável pelas reflexões partidárias sobre política externa e pelo aprofundamento da agenda internacional e dos contatos com lideranças no exterior (Nafalski, 2011; Nobre, 2013; Cruz, 2010). ${ }^{9}$

9 Apesar de inicialmente se considerar pós-social-democrata, o PT surgiu com uma base sindical característica das agremiações social-democratas. Segundo Singer (2012), Perry Anderson considera o PT como o único partido de trabalhadores 
Até recentemente, a política externa era considerada uma arena de baixa polarização, devido ao escasso rendimento eleitoral dos temas internacionais no Brasil. Isso explica por que as divergências tanto intrapartidárias quanto interpartidárias tendiam a emergir com mais nitidez, diferentemente dos demais temas. $\mathrm{Na}$ última década, entretanto, o posicionamento em torno de temas, como política externa e integração regional, tornou-se uma questão central na confrontação eleitoral entre coalizões e candidatos presidenciais na América do Sul. Nesse sentido, a postura a favor ou contra os processos de integração regional constitui um dos principais fatores de diferenciação eleitoral entre os candidatos presidenciais da direita e da esquerda (Caetano, 2011; Oliveira e Onuki, 2010). Enquanto o bloco liberal-conservador costuma defender acordos de livre comércio, especialmente com os países desenvolvidos, as forças de centro-esquerda defendem o fortalecimento do Mercosul e o aprofundamento da integração física e política da região.

Desde o governo Collor, há uma tendência à presidencialização da diplomacia brasileira, acentuada nos governos Fernando Henrique e Lula. A presidencialização significa a condução da política externa diretamente e de maneira rotineira pelo presidente, $o$ que implica a redução da autonomia decisória da chancelaria. Se, no passado, a delegação de autoridade era maior e o MRE desfrutava de mais autonomia, a presidencialização reduziu acentuadamente o poder político da burocracia diplomática, que passou a ter de responder diretamente às orientações presidenciais. De certa forma, a presidencialização evidenciou a politização do processo decisório, visto que a diplomacia presidencial dos governos Fernando Henrique e Lula passou a refletir de alguma maneira as concepções e as orientações político-partidárias dos dois mandatários (Amorim Neto, 2011; Lima e Duarte, 2013).

de massas criado no mundo após a Segunda Guerra Mundial. Ao tonar-se mais moderado, o PT aproximou-se da Internacional Socialista e de fundações como a Friedrich Ebert, ligada ao Partido Social-Democrata Alemão (SPD). 
O PT, quando na oposição, possuía uma postura bastante crítica em relação à política externa do governo Fernando Henrique; naquele período, o partido combateu a proposta da Alca, classificada com um projeto de anexação. Ao assumir o governo, o PT passou a adotar uma posição mais moderada, mas sem deixar de transferir para a política externa algumas linhas de seu pensamento. Isso ficou evidente, por exemplo, na nomeação de Marco Aurélio Garcia para a Assessoria Especial da Presidência da República para Assuntos Externos, o que significou uma mudança de procedimento, uma vez que o Itamaraty estava acostumado a fornecer diplomatas para aquela função. No caso do PSDB, sua passagem para a oposição levou a um endurecimento das críticas à política externa do novo governo, feitas por meio da comissão de relações exteriores do Senado, principalmente em relação às parcerias estratégicas e à integração regional (Almeida, 2003; Gavião, 2014; Mesquita, 2012a, 2012b). No entanto, pela primeira vez, as críticas passaram a incorporar expressões como "partidarização" e "ideologização", como se a política externa de Fernando Henrique e dos governos anteriores tivesse sido marcada pela neutralidade axiológica.

Segundo alguns especialistas, partidarização seria algo com conotação extremamente negativa, no sentido de que a política exterior não estaria de acordo com os "verdadeiros" interesses nacionais. É este o sentido utilizado pelos meios de comunicação e pela oposição nas críticas que fazem aos governos petistas. Já a acusação de viés ideológico está presente na crítica a diversas iniciativas da atual política externa, desde a suposta "política de generosidade” em relação aos vizinhos sul-americanos até o presumido rebaixamento da prioridade em relação aos países desenvolvidos. Os exemplos são muitos, e praticamente tudo que se afasta do relacionamento com os países do Norte é visto como pautado por viés partidário ou razões ideológicas (Lima e Duarte, 2013).

Para alguns analistas, a política externa dos governos do PT deixou de representar os interesses permanentes do Estado brasi- 
leiro. A oposição e a grande imprensa criticam a cooperação Sul-Sul, os traços antiamericanos e o presumível retorno ao terceiro-mundismo. Para a oposição liderada pelo PSDB e DEM, a forte politização deve-se à falta de concentração de esforços nas relações com os interlocutores políticos e econômicos tradicionais, como os Estados Unidos e a UE. Ainda, os opositores coincidem com as linhas editoriais da mídia hegemônica, simpáticas ao modelo econômico neoliberal e a uma inserção internacional voltada para o centro do sistema. No plano regional, os críticos denunciam as afinidades ideológicas ou partidárias como sendo responsáveis pelo desvirtuamento do Mercosul e pela criação de instituições com objetivos ideológicos, como a Comunidade dos Estados Latino-Americanos e Caribenhos (Celac) e a Unasul. Ademais, criticam a percepção que países como Bolívia e Paraguai teriam da fraqueza do Brasil por não reagir a atos contrários aos interesses nacionais (Barbosa, 2010, 2013; Gavião, 2014; Vigevani e Cepaluni, 2011).

Os defensores da atual política externa afirmam que ela tem sido responsável por uma maior projeção do país no mundo. Além disso, acusam as lideranças oposicionistas de atribuírem um papel secundário à região em seus programas partidários. Para os apoiadores da política exterior, ao Brasil não interessa ser uma nação próspera em meio a um conjunto de países pobres. Argumentam que o fato de ser maior impõe ao Brasil responsabilidades diferenciadas, principalmente em virtude do quadro de integração assimétrica. Em geral, muitos dos que criticaram a suposta tibieza da diplomacia brasileira para com a Bolívia e o Paraguai são os mesmos que, no passado, pregaram um comportamento subserviente em relação às grandes potências. Como afirma Garcia (2010, p. 164), "as preferências ideológicas eram outras".

Para os críticos da política externa dos governos Lula e Dilma, a diplomacia deixou de ser uma "política de Estado" e passou a ser uma "política de governo", contaminada por idiossincrasias partidárias e ideológicas que acabam provocando a divisão da sociedade. $\mathrm{O}$ 
pressuposto dessa crítica é que uma política externa de Estado seria consensual, como se sempre tivesse havido consenso nacional sobre a inserção do Brasil no mundo. No passado, tanto a PEI quanto o Pragmatismo Responsável foram objetos de críticas e resistências. Dessa forma, deve-se superar a falsa ideia de que a política externa não divide. Ela pode dividir e é bom que assim o seja, desde que as divergências e as discussões respeitem as regras democráticas (Garcia, 2014).

A interpretação corrente sobre a partidarização da política externa revela um sentimento tecnocrático, de negação da política, visto que, em uma democracia, a política externa é sempre politizada, refletindo de algum modo as orientações político-ideológicas do governo no poder (Lima e Duarte, 2013). Conforme análise de Amorim Neto (2011), estímulos sistêmicos, burocráticos e ideológicos se misturam de maneira complexa para ditar os rumos da diplomacia brasileira. Isso sugere cautela aos que somente enxergam ideologia na ação internacional recente do país. Uma explicação para os supostos excessos da atual política externa pode encontrar-se na atuação do Congresso, que costumava não ter voz autônoma em política exterior, pois era formado majoritariamente por parlamentares e partidos conservadores, os quais não demonstravam tanto interesse por temas internacionais. Todavia, desde a chegada do PT à Presidência da República, líderes e partidos conservadores têm atuado de forma mais incisiva em questões relativas à política externa, sem que isso signifique uma maior qualificação das discussões. Como lembra Sebastião Velasco e Cruz (2010), a pobreza do debate estratégico, nesse campo, condena a oposição ao discurso reativo da pequena política, ${ }^{10}$ tornando as lideranças opositoras caudatárias de seus grupos mais retrógados e menos representativos.

${ }^{10}$ Gramsci (2014) aplica os conceitos de pequena política (política do dia a dia; de corredor; de intrigas) e grande política (questões ligadas à fundação/destruição de Estados e às estruturas socioeconômicas orgânicas) à política internacional: 1) a grande política nas questões relacionadas à estrutura relativa de cada Estado nos confrontos recíprocos; 2) a pequena política nas questões diplomáticas que surgem 
A partir das eleições de 1994, a política externa deixou de ser um tema menor dos debates em curso no país. Nos últimos vinte anos, a política exterior se converteu em assunto com elevado grau de polarização entre PSDB e PT. Em seguida, com base na análise dos programas partidários, serão destacadas sinteticamente algumas propostas de política externa de cada um desses partidos nas eleições de 1994, 1998, 2002, 2006, 2010 e 2014.

Em 1994, o PSDB liderou a coligação "União, trabalho e progresso" e lançou o programa "Mãos à obra, Brasil: proposta de governo". Na introdução ao plano de governo, o partido afirmava que um novo modelo de desenvolvimento exigia a definição dos modos de sua inserção na economia internacional. Para isso, a política externa do país e sua política econômica precisariam estar conjugadas. Em relação às diretrizes de política externa, destacavam-se a defesa do multilateralismo e a ampliação do Conselho de Segurança das Nações Unidas (CSNU). Defendia-se o fortalecimento da presença brasileira no BID, no Banco Mundial, no FMI e na OMC, além de incentivar a cooperação com a Organização para Cooperação e Desenvolvimento Econômico (OCDE). O programa propunha também estudos sobre as perspectivas de o Brasil participar de zonas de livre comércio com a UE e o Tratado de Livre Comércio da América do Norte (Nafta). No plano bilateral, pregava-se o fortalecimento das relações com a América Latina, a América do Sul, os Estados Unidos, o Japão, além da ampliação do intercâmbio com a Rússia, a China, a Índia, os países africanos e os do Oriente Médio. Finalmente, defendia-se a consolidação do Mercosul e a realização de estudos para a criação da Área de Livre Comércio Sul-Americana (Alcsa), em um esforço para que a integração regional ultrapassasse a dimensão econômica e incluísse as áreas ambiental, educacional e cultural (Cardoso, 2008b).

no interior de um equilíbrio já constituído e que não tentam superar o equilíbrio estabelecido para criar novas relações. 
Em 1994, o PT liderou a coligação "Frente Brasil Popular". O problema básico da política externa brasileira, tal como detectado no programa "Uma revolução democrática no Brasil", era a ausência de um projeto nacional de desenvolvimento. Segundo o partido, com o fim da Guerra Fria, a antiga polarização Leste-Oeste teria deslocado a rivalidade entre as nações para o plano econômico, recompondo a oposição Norte-Sul em novas bases. De acordo com as diretrizes do programa, era preciso realizar profundas mudanças na ordem econômica internacional, especialmente no Banco Mundial e no FMI, além de democratizar a estrutura da ONU e do CSNU. A superação dessa realidade passava pela abertura de novos canais, como a cooperação econômica e política com a África do Sul, a China, a Índia e a Rússia. Em relação ao continente africano, enfatizava-se a necessidade de estabelecer linhas de cooperação, em particular com os povos de língua portuguesa. De maneira geral, o programa defendia a ênfase em programas de cooperação cultural e científica na esfera Sul-Sul. O Mercosul era visto como um processo alternativo aos acordos bilaterais com os Estados Unidos e por isso deveria ser fortalecido. No entanto, o PT defendia uma revisão do Tratado de Assunção para incorporar ao bloco as dimensões social e política. Ademais, o processo de integração centrado no Mercosul deveria ter como eixo a complementaridade produtiva e comercial entre os países-membros (PT, 1994).

A campanha de reeleição do presidente Fernando Henrique foi liderada pela coligação "União, trabalho e progresso". O programa "Avança, Brasil: proposta de governo" alertava para a necessidade de criar mecanismos capazes de atenuar os efeitos da volatilidade dos capitais financeiros, criticava os desequilíbrios no comércio internacional e denunciava o aumento das desigualdades causadas pela globalização. O programa ressaltava a importância de parcerias com a África do Sul, a China e a Rússia, destacando a aproximação entre a América Latina e a UE. Em relação à integração hemisférica, elogiava a ação diplomática que vinha permitindo que 
as negociações da Alca ocorressem em ritmo compatível com os interesses nacionais de longo prazo. No âmbito regional, o programa reafirmava a prioridade conferida ao Mercosul, defendendo seu fortalecimento institucional. O PSDB propunha ainda a organização de um espaço econômico sul-americano, baseado na integração da infraestrutura por meio de projetos em comum, a exemplo do gás boliviano e da energia elétrica venezuelana (Cardoso, 2008a).

Em 1998, Lula e Brizola lideraram a coligação "União do povo - muda Brasil”. No ponto 12 do programa, o PT propunha uma política externa que visasse alterar as relações desiguais e injustas do sistema internacional. A proposta defendia mudanças profundas nos organismos políticos e econômicos mundiais, citando expressamente o FMI, a ONU e a OMC. O programa ressaltava a necessidade de fortalecer as relações com os países do Sul, em especial com os da América Latina e da África meridional, destacando os de língua portuguesa. $\mathrm{Na}$ esfera regional, defendia a ampliação e a reforma do Mercosul, no sentido de reforçar sua capacidade de implementar políticas ativas comuns de desenvolvimento e de solução dos graves problemas sociais da região (PT, 1998).

Nas eleições de 2002, José Serra liderou a coligação "Grande aliança”. No programa apresentado, "Trabalho e progresso para todos", defendia-se a reforma de instâncias decisórias da comunidade internacional, destacando-se a ampliação do CSNU. Mencionava-se a vitória diplomática brasileira no âmbito da OMC, envolvendo o conflito entre propriedade intelectual e saúde pública. A proposta criticava a posição contraditória dos países desenvolvidos, que defendiam a abertura comercial, mas protegiam seus mercados. O programa defendia a necessidade de manter relações com os países desenvolvidos e de intensificar os laços políticos, econômicos e culturais com a China, a Índia e a Rússia, além de propor o aprofundamento da presença brasileira no continente africano, especialmente dos laços de cooperação com a África do Sul e os países de língua portuguesa. No âmbito hemisférico, a proposta mencionava a valorização da OEA e a necessidade 
de prosseguir nas negociações da Alca, desde que fosse adotada uma postura cautelosa e de defesa do interesse nacional. Na esfera regional, José Serra defendia o processo de integração da infraestrutura física e energética da América do Sul. Ademais, havia a intenção de flexibilizar a união aduaneira do Mercosul, consolidando o bloco como uma zona de livre comércio (PSDB, 2002).

Em sua quarta campanha presidencial em 2002, Lula esteve à frente da coligação "Lula presidente". O primeiro ponto do programa "Um Brasil para todos" afirmava que a política externa seria um meio fundamental para a implantação de um projeto de desenvolvimento nacional. No plano multilateral, mencionava-se a necessidade de uma articulação com países de importância regional - África do Sul, China, Índia e Rússia -, a fim de democratizar organismos internacionais como o Banco Mundial, o FMI e a ONU. As relações com os países desenvolvidos deveriam ser equilibradas. No plano hemisférico, o programa destacava os riscos de uma proposta de livre comércio entre países com grandes desníveis econômicos. Nesse sentindo, a Alca era vista como um processo de anexação econômica do continente, com graves consequências para a estrutura produtiva brasileira. Na esfera regional, propunha-se um pacto regional de integração da América do Sul. Além disso, o Mercosul deveria ser reconstruído e transformado em uma zona de convergência de políticas agrícolas, industriais, científicas, tecnológicas, educacionais e culturais (PT, 2002).

O tema da ideologização da política externa permeou a estratégia argumentativa do PSDB na campanha presidencial de 2006. A coligação "Por um Brasil decente" lançou a candidatura de Geraldo Alckmin. Ao invocar, logo no início do programa de governo, o "caráter consensual e suprapartidário" historicamente assumido pela política externa brasileira, o documento formulava elipticamente a crítica ao expressar que ela deveria ser vista como uma política de Estado, colocando o interesse nacional acima das visões conjunturais e ideológicas dos governos. Entre as propostas, o programa defendia que o Brasil se aproximasse da OCDE ou fosse acolhido por um G-8 
ampliado. O país deveria intensificar suas relações com os centros dinâmicos da economia global, além de ampliar seu relacionamento com a China, a Índia e a Rússia. Nesse último caso, as relações deveriam se basear na reciprocidade de interesses, e não na ilusão ideológica de que seriam aliados naturais. No plano hemisférico, defendia-se a retomada das negociações da Alca e a avaliação das possibilidades de acordos bilaterais de livre comércio como passos para o processo de integração continental. O programa defendia a integração física, energética e comercial da América do Sul, destacando que as relações com os países do entorno deveriam ocorrer com base em interesses recíprocos. Por fim, propunha-se a conclusão de um acordo entre Mercosul e UE e uma reflexão ampla sobre o bloco sul-americano (PSDB, 2006).

Em 2006, a coligação "Lula de novo com a força do povo" foi responsável pela reeleição do presidente. $\mathrm{O}$ programa defendia o fortalecimento do multilateralismo e a reforma das Nações Unidas e do CSNU. Havia críticas às assimetrias da ordem econômica internacional e ao caráter injusto e desigual da globalização. O Brasil deveria fortalecer as relações Sul-Sul, particularmente com os países africanos, ao mesmo tempo em que buscaria ampliar seu acesso aos grandes mercados asiático, europeu e norte-americano. O programa privilegiava o processo de integração sul-americano, destacando o Mercosul e a Comunidade Sul-Americana de Nações (Casa ou CSN). Ademais, propunha impulsionar a desdolarização do comércio com os países da América Latina e estimular a ampliação do mecanismo de Convênios de Crédito Recíproco - CCR (PT, 2006).

Em 2010, o PSDB lançou novamente José Serra, dessa vez à frente da coligação "O Brasil pode mais". O programa "Uma agenda para o desenvolvimento sustentável do Brasil” começava criticando a partidarização da política externa e a política de generosidade e afinidades ideológicas na América do Sul. Ou seja, a política exterior deveria retornar ao leito normal, com a continuidade necessária, sem grandes protagonismos. No plano multilateral, reafirmava-se 
a necessidade de reformar o CSNU. Diante do fracasso da Rodada de Doha da OMC, o Brasil precisaria seguir a tendência global de negociar acordos de livre comércio bilaterais com os mercados mais dinâmicos. Em matéria comercial, o Itamaraty deveria concentrar-se na formulação e na execução da política externa, cedendo sua competência de negociar assuntos comerciais para a Câmara de Comércio Exterior (CAMEX). No âmbito regional, o programa destacava a crise do Mercosul e criticava a entrada da Venezuela no bloco. Contraditoriamente, mencionava-se o fortalecimento do Mercosul, desde que fosse assegurada, ao Brasil e aos demais membros, mais flexibilidade para negociar individualmente acordos comerciais com outros mercados (PSDB, 2010).

Nas eleições de 2010, Lula apontou Dilma Rousseff como sua sucessora, à frente da coligação "Para o Brasil seguir mudando". O programa de governo propugnava a reforma da ONU e de outros organismos internacionais, como o Banco Mundial e o FMI, a fim de permitir a aplicação de políticas anticíclicas que possibilitassem a retomada do crescimento e o combate ao desemprego no mundo. A política externa deveria fortalecer o BRICS e o IBAS, sem prejuízo da continuidade das relações com os países desenvolvidos. $\mathrm{O}$ Brasil daria ênfase à integração com a África e a América do Sul, fortalecendo a Unasul e as políticas de integração física, energética, produtiva e financeira. O programa mencionava a importância de superar as divergências e fortalecer o Mercosul, além de destacar a necessidade de reduzir as assimetrias na região (PT, 2010).

Nas eleições de 2014, a polarização entre PSDB e PT quase foi rompida pela candidatura do Partido Socialista Brasileiro (PSB), sobretudo após a morte de Eduardo Campos e sua substituição por Marina Silva na liderança da chapa. O PSB foi o único partido a apresentar um programa de governo completo. $\mathrm{Na}$ área internacional, suas propostas convergiam em muitos pontos com as do PSDB, como, por exemplo, na defesa do fim das "diplomacias paralelas" e na revalidação da política externa como política de Estado. Apesar do 
bom desempenho eleitoral, a candidatura Marina Silva não logrou romper a polarização vigente há vinte anos. Por isso, a análise das eleições de 2014 limita-se aos programas do PSDB e do PT.

O candidato Aécio Neves liderou a coligação "Muda Brasil". Preliminarmente, o programa defendia que o objetivo da nova política externa era restabelecer seu tradicional caráter de política de Estado. O partido propunha a ampliação da ação diplomática em temas como meio ambiente, direitos humanos, democracia e comércio exterior, além da ampliação do CSNU. Advogava, também, uma reavaliação das prioridades estratégicas, enfatizando as relações com a Ásia, os Estados Unidos e demais países desenvolvidos e em desenvolvimento. As negociações comerciais deveriam pôr fim ao isolamento do Brasil, priorizando a abertura de novos mercados e a integração do país às cadeias produtivas globais. No âmbito regional, o Brasil deveria reexaminar as políticas adotadas, a fim de restabelecer a primazia da liberalização comercial, além de recuperar os objetivos iniciais do Mercosul e flexibilizar suas regras com o intuito de avançar nas negociações com terceiros países (PSDB, 2014).

A candidata à reeleição Dilma Rousseff esteve à frente da coligação "Com a força do povo". O programa destacava que, junto às políticas econômicas e sociais, os governos Lula e Dilma realizaram uma profunda mudança na presença do Brasil no mundo. $\mathrm{Na}$ esfera multilateral, o PT propunha a reforma dos principais organismos internacionais, cuja governança não refletia mais a correlação de forças global. Ao lado da importância conferida aos países desenvolvidos, o programa enfatizava as relações do Brasil com os países africanos, asiáticos e o mundo árabe. Ademais, a importância conferida aos países do Sul teria expressão concreta no papel do BRICS. No plano regional, a candidata reafirmava o compromisso de fortalecer o Mercosul, a Unasul e a Celac, sem discriminação de ordem ideológica. Além de enfatizar a integração financeira e das infraestruturas física e energética, o programa de governo sustentava 
que as transformações políticas e socioeconômicas dos últimos anos habilitariam a região a se tornar um importante ator no mundo multipolar em formação (PT, 2014).

Ao analisar os programas de política externa de PSDB e PT, é possível dividir as propostas em quatro grandes eixos: a) governança internacional; b) relações Norte-Sul e Sul-Sul; c) Alca; d) integração regional. Em relação ao primeiro eixo, a única convergência entre PSDB e PT se refere à reforma do CSNU, pois há diferentes visões sobre o alcance e profundidade das reformas que pretendem realizar nas demais organizações. No que diz respeito à segunda temática, apesar de ambos defenderem relações com os países desenvolvidos e em desenvolvimento, o PSDB enfatiza os laços com os países centrais, enquanto o PT prioriza as relações Sul-Sul. De fato, o termo "Sul" sequer é mencionado pelo PSDB. O terceiro eixo mostra-se bastante polarizado, embora não apareça em todos os programas, porquanto o governo Lula contribuiu para o encerramento da proposta estadunidense. As negociações da Alca revelaram clara divergência entre ambos, com o PSDB disposto a algum tipo de acordo e o PT frontalmente contrário à iniciativa. Por fim, o eixo da integração regional é o que possui maior grau de divergência entre os partidos; enquanto o PSDB defende a flexibilização do Mercosul e a assinatura de acordos de livre comércio com outras regiões, o PT enfatiza a necessidade de fortalecer o bloco e ampliar a integração sul-americana, destacando a importância de organizações, como a Unasul.

Em síntese, nos últimos vinte anos podem-se distinguir as posições dos dois partidos em consolidadas e cambiantes. Em relação às primeiras, tanto PSDB quanto PT mantiveram, ao longo do tempo, a essência de suas propostas em relação aos três primeiros eixos. No âmbito do sistema internacional, as reformas apresentadas pelo PSDB sempre foram mais moderadas do que as do PT. Ademais, aquele nunca atribuiu peso geopolítico às relações com outros países em desenvolvimento, ao contrário deste, que, desde 1994, enfatiza a 
cooperação Sul-Sul em seus aspectos econômico e político. Enquanto existiu a proposta da Alca, as duas agremiações mantiveram suas posições divergentes em relação ao assunto. $\mathrm{O}$ único eixo nitidamente cambiante é o que se refere à integração regional, que mostra como a chegada do PT ao poder e as transformações na conjuntura política da região deslocaram o PSDB para uma posição de centro-direita. Se, até 1998, o PSDB defendia o fortalecimento do Mercosul e a inclusão de outras dimensões ao projeto integracionista, a partir de 2002 o partido vai defender a flexibilização do bloco, enfatizando seu caráter comercial e criticando a politização do processo de integração regional. Desde 1994, o PT defende o Mercosul e a incorporação de uma dimensão política ao projeto sul-americano, o que ocorreria com a criação da Unasul. Portanto, é inegável que a diplomacia vem se afirmando como um novo atributo de identidade partidária no Brasil. A tabela 3 sintetiza as principais propostas de política externa dos dois partidos. 
Tabela 3 - Propostas de política externa de PSDB e PT (1994 a 2014)

\begin{tabular}{|c|c|c|}
\hline Eleiçôes & PSDB & PT \\
\hline \multirow{3}{*}{1994} & $\begin{array}{l}\text { Reformar o CSNU. Fortalecer a } \\
\text { presença brasileira no Banco Mun- } \\
\text { dial, no BID e na OMC. Cooperar } \\
\text { com a OCDE. }\end{array}$ & $\begin{array}{l}\text { Reformar o CSNU. Realizar profun- } \\
\text { das mudanças na ordem econômica } \\
\text { internacional, no Banco Mundial e } \\
\text { no FMI. }\end{array}$ \\
\hline & $\begin{array}{l}\text { Fortalecer as relações com Estados } \\
\text { Unidos e Japão. Ampliar o inter- } \\
\text { câmbio comercial com China, Ín- } \\
\text { dia, Rússia e países africanos. }\end{array}$ & $\begin{array}{l}\text { Cooperar com África do Sul, Chi- } \\
\text { na, Índia e Rússia. Enfatizar a coo- } \\
\text { peração Sul-Sul. }\end{array}$ \\
\hline & $\begin{array}{l}\text { Consolidar o Mercosul e incluir } \\
\text { as dimensões ambiental, cultural e } \\
\text { educacional na integração regional. }\end{array}$ & $\begin{array}{l}\text { Revisar o Tratado de Assunção e in- } \\
\text { corporar as dimensões social e políti- } \\
\text { ca ao Mercosul. }\end{array}$ \\
\hline \multirow{4}{*}{1998} & $\begin{array}{l}\text { Criar mecanismos para atenuar os } \\
\text { efeitos das crises financeiras causa- } \\
\text { das pela globalização. }\end{array}$ & $\begin{array}{l}\text { Reformar a ordem econômica in- } \\
\text { justa, a ONU, o FMI e a OMC. }\end{array}$ \\
\hline & $\begin{array}{l}\text { Fortalecer as parcerias com África } \\
\text { do Sul, China e Rússia. Aproximar } \\
\text { a América Latina da UE. }\end{array}$ & $\begin{array}{l}\text { Fortalecer relações com os países do } \\
\text { Sul, especialmente os da América } \\
\text { Latina e África. }\end{array}$ \\
\hline & Negociar a Alca no longo prazo. & - \\
\hline & $\begin{array}{l}\text { Organizar um espaço sul-america- } \\
\text { no baseado na integração da infraes- } \\
\text { trutura, a exemplo do gás boliviano } \\
\text { e da energia elétrica venezuelana. }\end{array}$ & $\begin{array}{l}\text { Ampliar o Mercosul e reforçar sua } \\
\text { capacidade de implementar políti- } \\
\text { cas ativas de desenvolvimento. }\end{array}$ \\
\hline \multirow{4}{*}{2002} & Ampliar o CSNU. & $\begin{array}{l}\text { Democratizar a ONU, o Banco } \\
\text { Mundial e o FMI. }\end{array}$ \\
\hline & $\begin{array}{l}\text { Manter relações com os países de- } \\
\text { senvolvidos e intensificar relações } \\
\text { com África do Sul, China, Índia e } \\
\text { Rússia. }\end{array}$ & $\begin{array}{l}\text { Fortalecer a articulação com paí- } \\
\text { ses de importância regional, como } \\
\text { África do Sul, China, Índia e Rús- } \\
\text { sia. }\end{array}$ \\
\hline & $\begin{array}{l}\text { Valorizar a OEA. Negociar cautelo- } \\
\text { samente a Alca. }\end{array}$ & $\begin{array}{l}\text { Denunciar a Alca como um proces- } \\
\text { so de anexação. }\end{array}$ \\
\hline & $\begin{array}{l}\text { Flexibilizar o Mercosul, converten- } \\
\text { do-o em zona de livre comércio. In- } \\
\text { tegrar a infraestrutura física e ener- } \\
\text { gética da América do Sul. }\end{array}$ & $\begin{array}{l}\text { Reconstruir o Mercosul e conver- } \\
\text { tê-lo em uma zona de convergência } \\
\text { de políticas agrícolas, industriais, } \\
\text { científicas, educacionais e culturais. }\end{array}$ \\
\hline
\end{tabular}




\begin{tabular}{|c|c|c|}
\hline \multirow{4}{*}{2006} & $\begin{array}{l}\text { Aproximar o Brasil da OCDE e do } \\
\text { G-8. }\end{array}$ & $\begin{array}{l}\text { Reformar o CSNU e fortalecer o } \\
\text { multilateralismo. }\end{array}$ \\
\hline & $\begin{array}{l}\text { Intensificar as relações com os paí- } \\
\text { ses centrais e ampliar os vínculos } \\
\text { com China, Índia e Rússia, sem ilu- } \\
\text { sões ideológicas. }\end{array}$ & $\begin{array}{l}\text { Fortalecer as relações Sul-Sul e am- } \\
\text { pliar o acesso aos mercados asiático, } \\
\text { europeu e estadunidense. }\end{array}$ \\
\hline & Retomar as negociações da Alca. & - \\
\hline & $\begin{array}{l}\text { Acelerar o acordo de livre comércio } \\
\text { entre Mercosul e UE. Estimular a } \\
\text { integração física, energética e co- } \\
\text { mercial da América do Sul. }\end{array}$ & $\begin{array}{l}\text { Priorizar a integração sul-america- } \\
\text { na, o Mercosul e a Casa/CSN. Esti- } \\
\text { mular a desdolarização do comércio } \\
\text { regional. }\end{array}$ \\
\hline \multirow{3}{*}{2010} & Reformar o CSNU. & $\begin{array}{l}\text { Reformar a ONU, o Banco Mun- } \\
\text { dial e o FMI. }\end{array}$ \\
\hline & $\begin{array}{l}\text { Negociar acordos de livre comércio } \\
\text { com mercados dinâmicos. }\end{array}$ & Fortalecer o BRICS e o IBAS. \\
\hline & $\begin{array}{l}\text { Flexibilizar o Mercosul, destacando } \\
\text { a crise do bloco e criticando a entra- } \\
\text { da da Venezuela. }\end{array}$ & $\begin{array}{l}\text { Superar divergências no Mercosul, } \\
\text { fortalecer a Unasul e reduzir as as- } \\
\text { simetrias regionais. }\end{array}$ \\
\hline \multirow{3}{*}{2014} & $\begin{array}{l}\text { Ampliar o CSNU e reforçar a ação } \\
\text { diplomática em temas como meio } \\
\text { ambiente, direitos humanos, demo- } \\
\text { cracia e comércio exterior. }\end{array}$ & $\begin{array}{l}\text { Reformar os principais organismos } \\
\text { internacionais. }\end{array}$ \\
\hline & $\begin{array}{l}\text { Enfatizar as relações com países de- } \\
\text { senvolvidos e em desenvolvimento. } \\
\text { Integrar o Brasil às cadeias produti- } \\
\text { vas globais, pondo fim ao seu isola- } \\
\text { mento. }\end{array}$ & $\begin{array}{l}\text { Enfatizar as relações com os países } \\
\text { africanos, asiáticos e o mundo árabe. } \\
\text { Priorizar os países do Sul e o BRICS, } \\
\text { sem prejuízo dos países desenvolvi- } \\
\text { dos. }\end{array}$ \\
\hline & $\begin{array}{l}\text { Recuperar os objetivos iniciais do } \\
\text { Mercosul, flexibilizar suas regras e } \\
\text { reestabelecer a primazia da liberali- } \\
\text { zação comercial na região. }\end{array}$ & $\begin{array}{l}\text { Fortalecer o Mercosul, a Unasul e a } \\
\text { Celac, sem discriminações ideológi- } \\
\text { cas. Integrar a infraestrutura física, } \\
\text { energética e financeira da América } \\
\text { do Sul, região que pode se tornar um } \\
\text { importante ator no mundo multi- } \\
\text { polar em formação. }\end{array}$ \\
\hline
\end{tabular}

Fonte: O autor, 2014. 


\subsection{Governo Fernando Henrique: reformas de mercado e diplomacia das credenciais}

O governo Fernando Henrique Cardoso (1995-2002) implementou políticas que alteraram profundamente o modelo econômico, a sociedade e a inserção internacional do Brasil. Por um lado, as reformas liberais, conquanto mais moderadas do que nos demais países latino-americanos, desmontaram sistematicamente o modelo nacional-desenvolvimentista. Por outro, apesar da importante conquista da estabilidade monetária, as políticas ortodoxas geraram efeitos adversos na estrutura produtiva e no tecido social. Nesse contexto, a política externa brasileira tornou-se subsidiária à estabilidade macroeconômica, adquirindo a função de garantir a credibilidade por meio da modernização econômica e da maior participação do país nos regimes internacionais.

O Brasil ingressou no neoliberalismo tardiamente, e foi o país em que as reformas mais se distanciaram do modelo neoliberal clássico. A intensidade das pressões por liberalização econômica depende de variáveis, como posicionamento geopolítico, nível de desenvolvimento e capacidades estatais. De fato, os contextos históricos de aplicação das reformas foram muito distintos nos casos de Argentina, Brasil e Chile. Em todos eles, a dependência de trajetória contou muito, pois nas nações vizinhas o neoliberalismo foi introduzido pelos regimes ditatoriais da década de 1970. Ademais, a situação em que cada país encarou a nova fase de acumulação capitalista, em meados dos anos 1990, acabaria sendo crucial para seu desenvolvimento posterior. No Brasil, devido ao menor ritmo e gradualismo, as reformas setoriais preservaram alguns núcleos de excelência burocrática, mantendo instituições de fomento, como o BNDES, que, apesar de convertido em agente da privatização, preservou o protagonismo da era desenvolvimentista. Isso decorreu tanto da existência de poderosas estruturas domésticas quanto de formas de pensar profundamente 
enraizadas em setores da sociedade e do Estado (Boschi e Gaitán, 2008; Domingues, 2013; Hurrell, 2009b).

Para entender o ambiente de implementação das reformas durante o governo Fernando Henrique, deve-se analisar o contexto das décadas 1980 e 1990 . Nesse período, a ideologia neoliberal passou a questionar a tese do desenvolvimento vinculado diretamente à ação ativa do Estado. As críticas dirigiam-se sobretudo ao "Estado desenvolvimentista". Ao mesmo tempo que os argumentos pró-mercado ganhavam força, surgiam propostas de um novo desenho para o Estado, que eram formuladas com o intuito de reconstruí-lo em conformidade com as novas "exigências" do mundo globalizado. Nos anos 1990, as recomendações de reformas aos países periféricos foram amplamente difundidas e consistiam em dois momentos: reformas de primeira e segunda geração (Ugá, 2008).

O conjunto de reformas implicava a adoção de uma série de "boas políticas" (primeira geração) e "boas instituições" (segunda geração). De acordo com Ha-Joon Chang (2004), para essa agenda, as "políticas boas" eram aquelas prescritas pelo chamado Consenso de Washington. Já as "instituições boas" seriam aquelas existentes nos países desenvolvidos, principalmente nos anglo-saxões.

O principal objetivo do receituário do Consenso de Washington era fazer com que a América Latina conseguisse sair da crise por que passava (estagnação, inflação, dívida externa) e retomasse uma trajetória de crescimento. Nesse sentido, as dez propostas apresentadas por John Williamson envolviam: 1) disciplina fiscal e redução do déficit orçamentário; 2) redirecionamento do gasto público em áreas desinteressantes para o investimento privado - geralmente para bens públicos; 3 ) reforma tributária, visando a alargar a base tributária e tornar a tributação menos progressiva; 4) liberalização financeira, cujo objetivo final era fazer com que a taxa de juros fosse determinada pelo mercado; 5) taxa de câmbio competitiva para induzir o crescimento das exportações não tradicionais; 6) liberalização comercial; 7) abolição de barreiras à entrada de investimentos 
externos diretos; 8) privatização de empresas estatais; 9) abolição de regulamentos que impedissem a entrada de novas empresas ou restringissem a competição; e 10) sistema jurídico que assegurasse direitos de propriedade (Ugá, 2008; Williamson, 2004).

O principal objetivo desse decálogo era inserir as economias nacionais no processo de internacionalização do capital e iniciar o processo de reforma do Estado, reduzindo seu tamanho e reconstruindo sua estrutura administrativa. Por um lado, o Estado deveria redimensionar sua atuação, renunciando ao seu papel intervencionista e atuando de modo a promover o bom funcionamento do mercado; para isso, faziam-se necessárias medidas como o ajuste fiscal e o processo de privatizações. Por outro, a reforma administrativa visava a transformar a administração pública burocrática em gerencial, por meio da utilização de instrumentos administrativos do setor privado. Assim, o aparelho estatal deveria estar voltado para a redução de custos e o aumento da eficiência (Ugá, 2008).

As reformas de segunda geração tinham como objetivo, por um lado, aprofundar e completar as reformas anteriores e, em contrapartida, iniciar um novo ciclo reformista, dessa vez voltado à reestruturação institucional. Entre as instituições-chave, incluíam-se uma burocracia “boa”, um judiciário independente, o reforço dos direitos de propriedade privada (inclusive a intelectual), uma governança empresarial transparente e instituições financeiras autônomas, como a garantia de um banco central politicamente independente. Assim, a reforma dessas instituições deveria garantir as bases para o crescimento voltado para o mercado (Chang, 2004; Ugá, 2008; Williamson, 2004).

As reformas institucionais preconizavam que os Estados latino-americanos deveriam deixar progressivamente seu papel ativo no desenvolvimento nacional para assumir um papel funcional - de facilitador - ao desempenho dos mercados. Nesse sentido, a atuação do Estado deveria ser limitada à redução dos custos de transação, à garantia dos direitos de propriedade, à coordenação dos agentes 
econômicos, à geração de informações relevantes e à redução de incertezas (Ugá, 2008).

Obviamente, a redução das funções do Estado a um mero complemento dos mercados, como criador de um ambiente favorável ao setor privado, também teve implicações sobre a área social, ao criar obstáculos para a consolidação e ampliação do sistema de proteção social dos países latino-americanos. A gestão neoliberal do Estado implica conduzi-lo como se fosse um negócio, mas o resultado é o inverso do que ocorre quando essa racionalidade é aplicada ao setor privado. No lugar de um acúmulo de recursos e da reprodução ampliada do capital público, há a dilapidação dos recursos estatais, o encolhimento do tamanho do Estado e o atrofiamento do espaço econômico público. Isso produz o aumento da espoliação e da mercantilização das esferas da vida social (Paulani, 2008; Ugá, 2008). ${ }^{11}$

Nos anos 1990, os governos brasileiros adotaram uma agenda de desenvolvimento baseada no mercado e no Consenso de Washington. Tal agenda responsabilizava o modelo de substituição de importações e o tamanho do Estado pelos problemas econômicos estruturais do país. A partir de 1995, Fernando Henrique acelerou o processo de abertura e privatização na tentativa de superar, como ele mesmo havia dito pouco tempo antes, a Era Vargas. Assim, por meio de emendas à constituição, redefiniram-se as relações entre o Estado e o setor privado. Muitas áreas anteriormente operadas pelo Estado foram abertas aos investidores privados. Foram privatizados, então, os bancos estaduais, a Companhia Vale do Rio Doce e o sistema Telebrás, totalizando

\footnotetext{
${ }^{11}$ Entre o pós-guerra e meados dos anos 1970, surgiu nos países centrais aquilo que Francisco de Oliveira chamou de "direitos do antivalor". O Estado de bem-estar possibilitou a criação de um lócus no qual um volume cada vez mais expressivo de mercadorias deixava de ter seus valores determinados pelo mercado e pela acumulação privada, colocando como questão política a determinação do valor da força de trabalho, da saúde, da educação etc. Com a hegemonia neoliberal, afirmou-se cegamente o espaço do valor e do capital. Essa nova característica do capitalismo se mostra muito mais marcada e dura na periferia do sistema (Paulani, 2008).
} 
receitas superiores a US\$ 100 bilhões. Em tese, o objetivo já não era apenas privatizar para liberar o Tesouro do ônus de sustentar algumas empresas deficitárias, mas ter uma estratégia de integração competitiva do país à economia internacional, atraindo capitais e tecnologia do exterior. Na prática, todavia, o investimento externo direto não se converteu em expansão da capacidade produtiva, mas na desnacionalização e na concentração das empresas, além da entrada de capital especulativo atraído pelas altas taxas de juros (Cardoso, 2010; Kerstenetzky, 2014; Pedersen, 2008).

Para ser bem-sucedida, a política anti-inflacionária vinculou-se à abertura econômica, que foi sustentada pelo câmbio valorizado e pelas altas taxas de juros. ${ }^{12}$ De um lado, a liberalização comercial facilitou a importação rápida e barata de produtos que estavam pressionando os preços domesticamente. De outro, a liberalização financeira contribuiu para atrair capitais para financiar os déficits do governo, que se endividava substancialmente com as altas taxas de juros, levando à apreciação do Real. Deve-se observar que a manutenção do câmbio valorizado desrespeitava o item 5 do decálogo do Consenso de Washington, que recomendava uma taxa de câmbio competitiva capaz de favorecer o crescimento rápido das exportações não tradicionais (Cano, 2014; Gonçalves, 2013; Nobre, 2013; Williamson, 2004).

${ }^{12}$ Os custos da estabilização tiveram impactos negativos sobre a dívida pública. Sua proporção relativa ao PIB passou de 30\%, em 1994, para mais 50\%, em 2002. Isso ocorreu mesmo se contabilizadas as receitas decorrentes da privatização do patrimônio público e do aumento da carga tributária, que subiu de $25 \%$ para $32 \%$ do PIB. O aumento da dívida foi acompanhado da transformação da dívida externa do setor público em dívida interna. Assim, entre 1993 e 2002, a dívida interna passou de $18,8 \%$ para $41,2 \%$ do PIB, enquanto a dívida externa permaneceu praticamente inalterada, em torno de $14 \%$ do produto. Esse processo de conversão da dívida deve ser entendido como uma medida defensiva. Por não ter condição de acumular reservas suficientes e de haver renunciado ao controle de capitais, uma das maneiras de reduzir a vulnerabilidade externa foi oferecer títulos públicos a juros elevados, porém denominados em reais (Nobre, 2013). 
O governo Fernando Henrique foi marcado pela ausência de uma política industrial ativa. A criação do Ministério do Desenvolvimento, Indústria e Comércio Exterior (MDIC), em 1998, veio acompanhada de medidas de concessão de empréstimos para as exportações. No entanto, o plano "Nova Política Industrial: desenvolvimento e competitividade" não previa instrumentos de política industrial, apenas reiterava a importância da competitividade e da estabilidade macroeconômica (Pedersen, 2008). No âmbito do governo, havia uma predominância dos setores neoliberais ortodoxos, colocando em posição minoritária os chamados desenvolvimentistas, que defendiam uma política industrial ativa. Apesar do entusiasmo que o empresariado industrial demonstrou pela estabilização monetária, o apoio do setor ao governo começaria a minguar ainda no primeiro mandato (Nobre, 2013).

Com a abertura da economia brasileira, pretendia-se aumentar a competitividade das empresas instaladas no país. Esperava-se que as companhias capazes de se reestruturar e sobreviver à competição internacional se tornassem mais fortes. No entanto, a abertura comercial complementou o efeito nocivo do câmbio valorizado. $\mathrm{O}$ incremento das importações quebrou ou debilitou elos de várias cadeias produtivas, eliminando muitas empresas. ${ }^{13} \mathrm{Em} 1990$, produtores domésticos eram responsáveis por $80 \%$ do suprimento da demanda por máquinas e equipamentos, participação que foi reduzida a menos de 50\%, sete anos depois. Essas transformações modificaram o equilíbrio do tripé desenvolvimentista entre propriedade estatal, capital privado nacional e capital estrangeiro, como mostra

${ }^{13}$ Cano (2014) menciona a destruição de algumas importantes empresas nacionais, como a Metal Leve, do setor de autopeças. A Kasinski, que antes produzia peças para exportar aos mercados norte-americano e europeu, transformou-se em simples montadora de motocicletas na Zona Franca de Manaus, antes de ser vendida ao capital estrangeiro. Há, ainda, o caso da Hering, grande empresa têxtil nacional, que transitou da produção industrial para atividades predominantemente comerciais. 
a tabela 4 (Cano, 2014; Domingues, 2009; Kerstenetzky, 2014; Nobre, 2013; Pedersen, 2008).

Tabela 4 - Brasil: Distribuição da propriedade industrial, 1983$2000(\%)$

\begin{tabular}{lccc}
\hline & $\mathbf{1 9 8 3}$ & $\mathbf{1 9 8 9}$ & $\mathbf{2 0 0 0}$ \\
\hline Empresas privadas nacionais & 53,4 & 59,1 & 50,2 \\
Empresas estatais & 26,4 & 23,8 & 15,2 \\
Empresas transnacionais & 20,2 & 17,1 & 34,6 \\
\hline
\end{tabular}

Fonte: Pedersen, 2008.

A reestruturação produtiva intensificou a especialização das empresas domésticas, tornando as que sobreviveram mais competitivas. Todavia, a diminuição da diversificação favoreceu indústrias com baixo conteúdo tecnológico, concentradas em commodities industriais (a exemplo do aço), reforçando a chamada "especialização regressiva”. Além disso, entre os efeitos deletérios da reestruturação produtiva, estavam a desindustrialização e o aumento do desemprego. Os esforços internos em $\mathrm{P} \& \mathrm{D}$ nas empresas privatizadas foram reduzidos, pois elas passaram a importar de suas matrizes e de seus fornecedores globais. As tecnologias de informática aplicadas à produção se disseminaram nas grandes firmas, em geral transnacionais, mas não entre as empresas pequenas e médias. Os reflexos dessas mudanças não tardaram a se refletir na pauta de exportações. Em 1990, a participação dos produtos industriais no total das exportações brasileiras era de $80,5 \%$; em 2000, já se encontrava em 32,1\% (Cano, 2014; Domingues, 2009; Kerstenetzky, 2014).

De acordo com os ideólogos do governo, o choque de concorrência desencadeado pela abertura levaria à reestruturação produtiva que, por sua vez, faria elevar os salários graças ao aumento da produtividade, contribuindo para o crescimento econômico e a redução das desigualdades distributivas. No entanto, a evolução 
desproporcional da produção vis-à-vis o emprego parecia indicar que equipamentos e processos poupadores de trabalho estavam sendo utilizados no curso da modernização industrial. Entre 1995 e 1999, extinguiu-se 1,8 milhão de empregos no setor formal, a maioria na indústria. Ainda, o aumento da subcontratação e a dispersão geográfica das áreas industriais contribuíram para aprofundar a fragmentação da classe trabalhadora. Durante nove anos seguidos, entre 1995 e 2004, houve diminuição da participação salarial na renda nacional, que perdeu $9 \%$, enquanto as rendas de propriedade - aluguéis, juros, lucros, renda da terra - cresceram 12,3\% no mesmo período (Domingues, 2009; Kerstenetzky, 2014; Paulani, 2008; Pochmann, 2012).

Apesar das elevadas taxas de desemprego e da redução da massa salarial, o governo Fernando Henrique iniciou a implementação de uma rede de proteção social multifacetada dispersa por vários ministérios, cuja prioridade era focalizar o público-alvo de menor renda, em harmonia com as políticas de alívio à pobreza propostas pelo Banco Mundial. Além disso, vários dispositivos da Constituição de 1988 foram regulamentados, levando à expansão dos gastos sociais. Em 1996, a aprovação do Fundo de Manutenção e Desenvolvimento do Ensino Fundamental e de Valorização do Magistério (FUNDEF) elevou os gastos com educação e contribuiu para a universalização do ensino médio. Entre 1993 e 1996, a Lei Orgânica da Assistência Social (LOAS), aumentou os gastos de assistência social e o contingente de beneficiários (Cardoso, 2010; Kauchakje, 2014; Kerstenetzky, 2014, Nobre, 2013). No entanto, a manutenção de altas taxas de juros preservou a renda dos estratos mais ricos e o padrão desigual de distribuição de renda vigente no país. Esse foi o preço pago pelo controle da inflação nos marcos do Plano Real.

Ao manter a moeda valorizada, o governo gerou mega déficits em transações correntes. $\mathrm{O}$ déficit na balança de rendas (dividendos, juros e lucros), que girou em torno de US\$ 11 bilhões entre 1980 e 1996, saltou para US\$ 15 bilhões em 1997, para US\$ 19 
bilhões a partir de então. A enxurrada de importações produziu déficits no saldo em transações correntes, que somaram, de 1991 a 2000, US\$ 493 bilhões. Com isso, a piora estrutural das contas externas aumentou a vulnerabilidade externa brasileira. A partir dos efeitos da moratória russa de agosto de 1998, o país foi alvo de um ataque especulativo que retraiu suas reservas a cerca de US\$30 bilhões. Com o apoio do governo estadunidense, o Brasil assinou um acordo de US\$ 41,5 bilhões com o FMI. Em janeiro de 1999, o Banco Central adotou um câmbio flutuante e permitiu que a moeda se desvalorizasse. Desde então, o governo Fernando Henrique passou a adotar o tripé macroeconômico formado por câmbio flexível, regime de metas de inflação e superávit primário. Devido à vulnerabilidade externa, o governo recorreria ainda duas vezes ao FMI, obtendo US $\$ 15$ bilhões, em 2001, e US\$ 30 bilhões, em 2002 (Cano, 2014; Gonçalves, 2013; Hirst, 2009; Nobre, 2013; Paulani, 2008; Pedersen, 2008).

No plano institucional, Fernando Henrique esteve à frente de uma ampla e sólida coalizão parlamentar, nucleada no PSDB, no PFL e no PMDB, a qual lhe proporcionou o governo mais estável, do ponto de vista político, dos dois períodos democráticos brasileiros (Amorim Neto, 2011). A estabilização da economia teve como contrapartida a centralização dos instrumentos de política econômica no governo central, possibilitando a substituição do "velho pemedebismo" da década de 1980 por um "novo pemedebismo". Segundo Nobre (2013), em lugar dos dois extremos - o travamento pemedebista e o cesarismo de Collor -, surgiu um novo centro político e a partir dele dois polos, um liderado pelo PSDB e o outro pelo PT. Dessa forma, situação e oposição polarizadas reorganizou o debate público, embora os canais de expressão da oposição fossem bastante limitados, em consequência tanto do superbloco parlamen- 
tar de apoio ao governo quanto do processo de desmobilização social que se seguiu à aplicação do receituário neoliberal. ${ }^{14}$

A política externa e a inserção internacional de um país refletem a dinâmica do poder doméstico e os interesses da coalizão política hegemônica. O governo do PSDB liderou forças defensoras da ortodoxia neoliberal ligadas ao capital financeiro, a frações da burguesia associadas ao capital internacional, às empresas de comunicação e à alta classe média. Fernando Henrique foi decisivo na consolidação dessa coalizão de centro-direita, rejeitando qualquer aliança com movimentos e forças sociais organizadas. Com os empresários do setor industrial, as relações eram no mínimo truncadas. Nesse sentido, a coalizão de interesses rentistas teve sucesso na aplicação das reformas liberalizantes e na adaptação relativamente passiva do país à globalização econômica e financeira (Boito e Berringer, 2014; Domingues, 2013; Singer, 2012).

Na política externa, Fernando Henrique exerceu ativamente a diplomacia presidencial, esvaziando o Itamaraty de algumas funções, uma vez que esse órgão ainda possuía alguns núcleos ligados ao projeto nacional-desenvolvimentista. O presidente transferiu certas atribuições econômicas do MRE para o Ministério da Fazenda. Além disso, o novo mandatário procurou substituir uma agenda de política externa reativa - que havia prevalecido durante a vigência do modelo de substituição de importações - por uma agenda proativa, alinhada em alguns temas ao projeto neoliberal. Assim, em vez de uma autonomia isolacionista, buscou-se uma autonomia articulada com o meio internacional, baseada em uma estratégia de adesão unilateral a diferentes regimes internacionais (Vigevani e Cepaluni, 2011; Visentini, 2013).

${ }^{14}$ A repressão à greve dos petroleiros em 1995, quando tropas do exército ocuparam as refinarias da Petrobras, e a elevação do desemprego a partir de 1996 fizeram o número de greves despencar de uma média anual de 1102, entre 1985 e 1989, para 440, entre 1999 e 2002 (Singer, 2012). 
As prioridades da política externa passaram a se subordinar à estabilização monetária e às reformas na economia. A política exterior passou a ter como objetivo primordial a restauração da credibilidade econômica e política do Brasil (Lima e Duarte, 2013). Durante o primeiro mandato de Fernando Henrique (1995-98), o sentido geral da política externa visava a obter as credenciais entendidas como necessárias para que o país pudesse inserir-se em condições mais favoráveis no cenário internacional. Investiu-se pesadamente no soft power da credibilidade, que exigia a participação plena em todos os regimes internacionais. Nesse sentido, Alexandre Parola (2007) tem razão quando chama de "Diplomacia das Credenciais" a política externa do primeiro governo Fernando Henrique.

Segundo a lógica da busca de credibilidade, por não ter um "superávit de poder", a ampliação da autonomia nacional passava pela capacidade de cooperar na criação de regras e instituições. A completa adesão aos regimes internacionais possibilitaria a convergência da política externa brasileira com as tendências mundiais, evitando o isolamento do país. Para os formuladores da política exterior, isso não significava subordinação, pois asseguraria o fortalecimento da posição relativa do Brasil no sistema internacional. Assim, Fernando Henrique deu continuidade à iniciativa dos governos Collor e Itamar. Na esfera de defesa, o país aderiu ao Tratado de Tlatelolco (1994), que previa a proibição de armas nucleares na América Latina e no Caribe; aprovou a legislação sobre o controle de exportação de materiais nucleares e ingressou no Regime de Controle de Tecnologia de Mísseis (1995); tornou-se membro do Grupo de Fornecedores Nucleares (1996); e ratificou o Tratado de Não Proliferação Nuclear (1998). Esse conjunto de medidas de contraproliferação, adotadas de maneira unilateral, alterou a autopercepção do país no sistema internacional. $\mathrm{Na}$ área ambiental, o Brasil abandonou a postura defensiva dos anos 1980 e caminhou rumo ao reconhecimento das questôes ambientais e das atividades de ONGs, desempenhando um importante papel nas negociações da 
Rio-92. No campo dos direitos humanos, o Brasil ratificou o Pacto Internacional sobre Direitos Civis e Políticos (1992), destacou-se na Conferência Mundial de Direitos Humanos em Viena (1993), anunciou que reconheceria a competência da Corte Interamericana de Direitos Humanos (1998) e decidiu assinar o estatuto do Tribunal Penal Internacional (1999) (Hurrell, 2009b; Vigevani e Cepaluni, 2011).

O Brasil participou ativamente nas negociações das regras e da construção do regime multilateral de comércio. $\mathrm{O}$ número de casos em que o país recorreu a medidas compensatórias e de antidumping cresceu expressivamente a partir de 1996. Na relação com os Estados Unidos, as vendas de produtos derivados do aço tornaram-se o principal alvo das ações norte-americanas, ainda que o açúcar, os calçados, o suco de laranja e o tabaco também devam ser mencionados. Do lado brasileiro, as reclamações se concentraram nos produtos siderúrgicos e no algodão; no entanto, o contencioso de maior relevância social envolveu o governo brasileiro e as grandes empresas farmacêuticas, especialmente as estadunidenses: o Brasil exigiu o reconhecimento do direito de quebra de patentes de remédios para o tratamento da Aids, pois a produção de drogas genéricas antirretrovirais a custos mais baixos era de extrema importância para sua política de saúde. Utilizando o argumento de que o bem público deveria prevalecer sobre $\mathrm{o}$ lucro, o país legitimou sua demanda e obteve o apoio de outros países da OMC, da ONU, da Organização Mundial de Saúde (OMS) e de ONGs envolvidas com a temática. Por ocasião do início da Rodada de Doha, em 2001, foram formadas duas coalizões, uma liderada por Brasil e Índia e outra pelos Estados Unidos. Finalmente, os norte-americanos mudaram sua posição e aceitaram a possibilidade de quebra de patentes em questões de saúde pública (Hirst, 2009; Pedersen, 2008; Vigevani e Cepaluni, 2011).

No governo Fernando Henrique, consolidou-se, ao menos na retórica, uma política voltada ao entorno geográfico. De certa forma, o Mercosul deveria atender tanto aos interesses do setor 
industrial brasileiro quanto à política de inserção competitiva na economia global. Nos anos 1990, o bloco se afastou da moldura desenvolvimentista do Tratado de Integração, Cooperação e Desenvolvimento de 1988, para adotar o formato de regionalismo aberto, possibilitando ao Brasil simultaneamente aderir às normas e aos regimes internacionais de seu interesse e garantir a preservação de uma reserva de autonomia. Nessa época, o conceito de América do Sul passou a se sobrepor ao de América Latina. A partir de sua adesão ao Nafta, o México comunicou que não estenderia mais aos países da Associação Latino-Americana de Integração (Aladi) as preferências comerciais que eles se concediam mutuamente. Ao aumentar seu grau de interdependência com os Estados Unidos, os mexicanos tinham se deslocado da América Latina, fazendo com que a diplomacia brasileira considerasse cada vez mais o entorno sul-americano como sua área estratégica. Assim, a construção da identidade do Brasil como país latino-americano foi paulatinamente substituída pela ideia de país sul-americano (Lafer, 2004; Lampreia, 2010; Lima e Hirst, 2009; Pedersen, 2008; Vigevani e Cepaluni, 2011). Como bem sintetizou Celso Lafer (2004, p. 52), “para o Brasil a América do Sul não é uma opção e, sim, para falar como Ortega y Gasset, a 'circunstância' do nosso eu diplomático”.

A proposta da Alca levou o Brasil a priorizar o Mercosul. Em 1994, na Cúpula de Miami, quando o presidente Clinton resolveu transformar aquela ideia em questão central de sua política latino-americana, o governo brasileiro assumiu uma atitude defensiva e enfatizou um cronograma gradualista, temendo que o Mercosul e a Alca fossem mutuamente excludentes. A partir da Cúpula de Santiago, em 1998, a diplomacia brasileira passou a defender que os países do Mercosul negociassem em bloco com os Estados Unidos. Ao final do governo Fernando Henrique, as divergências entre Brasil e Estados Unidos aumentaram, justamente quando ambos passaram a presidir a proposta de integração hemisférica, cuja data-limite para se chegar a um acordo era 2005 (Hirst, 2009; Hurrell, 2009b). 
Apesar da postura defensiva, predominava no governo brasileiro a visão de que a Alca representaria mais uma oportunidade do que uma ameaça.

No segundo mandato de Fernando Henrique (1999-2002), houve uma combinação entre a deterioração do cenário econômico internacional, o aprofundamento da crise socioeconômica interna e a mudança do ambiente político mundial. A partir daí, o diagnóstico sobre as possibilidades de a ordem internacional acolher os interesses nacionais alterou-se sensivelmente. A visão otimista da globalização neoliberal foi substituída pela crítica à globalização assimétrica. Diante da falta de reciprocidade dos países europeus e dos norte-americanos, o governo brasileiro percebeu os limites da estratégia de autonomia pela participação, quando as credenciais já não bastavam (Parola, 2007; Vigevani e Cepaluni, 2011; Visentini, 2013).

Com a ascensão de Bush, em 2001, o unilateralismo da política externa estadunidense, sobretudo após os atentados de $11 \mathrm{de}$ setembro, evidenciou ainda mais os limites do conceito de autonomia pela participação. O governo Fernando Henrique também vislumbrava encontrar uma parceria mais sólida com os países europeus, mas o compartilhamento de valores não foi suficiente para que houvesse uma reciprocidade da UE em relação ao Brasil e aos seus parceiros do Mercosul. Isso levou a política externa brasileira a ampliar suas relações com a África do Sul, a China e a Índia, sem, contudo, institucionalizar qualquer parceria. A ausência de resultados concretos desacreditava a estratégia da busca por credibilidade, que nunca fora consensual no Estado, inclusive entre os membros da comunidade de política externa. No âmbito do Itamaraty, abriu-se espaço para o surgimento de outra estratégia, que priorizava a autonomia, maior projeção internacional, política desenvolvimentista ativa, a colaboração com outros países periféricos e a necessidade de articular um projeto nacional de desenvolvimento capaz de superar os desequilíbrios sociais domésticos (Lima e Hirst, 2009; Vigevani e Cepaluni, 2011). 
Em resumo, nos anos 1990, o Brasil introduziu reformas de mercado que alteraram a estrutura social e econômica do país, com reflexos em sua política exterior, gerando estagnação econômica, desemprego recorde, aumento da vulnerabilidade externa e permanência do padrão distributivo desigual. Ao tentar superar o modelo nacional-desenvolvimentista, Fernando Henrique acelerou o processo de desindustrialização relativa, com o rompimento dos nexos interindustriais das principais cadeias de produção, causando claro retrocesso no perfil da estrutura produtiva e na forma de inserção do Brasil na produção mundial. No âmbito da diplomacia, a adesão a regimes internacionais e a aproximação com os países desenvolvidos não causaram os retornos esperados. Por fim, a recepção acrítica do receituário neoliberal teve impactos negativos nas ideias de autonomia e desenvolvimento, que, historicamente, influenciaram a política externa brasileira.

\subsection{Governos Lula e Dilma: rearticulação entre política exter- na e desenvolvimento}

Após duas décadas de hegemonia de governos neoliberais, a vitória de Luís Inácio Lula da Silva inaugurou um novo ciclo na região, com a ascensão de governos progressistas que introduziram políticas sociais distributivas, fortaleceram a capacidade de intervenção do Estado e formularam políticas externas mais autônomas. O declínio do projeto conservador cedeu lugar a processos de caráter endógeno, gerados nas lutas sociais de cada nação, levando ao surgimento de lideranças que conseguiram se firmar superando todos os preconceitos e quebrando as barreiras históricas impostas pelas elites desses países. Assim, o insucesso econômico e social das políticas neoliberais contribuiu decisivamente para a "virada à esquerda" dos governos da América do Sul durante a primeira década do século XXI. 
Os governos progressistas do Brasil e da região adotaram políticas públicas na contracorrente da acumulação capitalista mundial, mitigando o padrão flexível e polarizado que prevalecia há décadas. Esses governos criaram um mercado de consumo de massas, um "keynesianismo dos pobres", incorporando vastos contingentes de consumidores. Tais administrações incrementaram os gastos sociais estatais, afastando-se do modelo do período neoliberal baseado em provisóes sociais privadas. As esquerdas moderada e contestatória adotaram programas sociais que combinaram benefícios focalizados em políticas universais; ambas conceberam o Estado como o principal instrumento para remodelar suas respectivas sociedades. Diferentemente dos governos neoliberais, os governos progressistas compreenderam que a extinção da pobreza exigia intervenções que só podiam ser efetuadas por instituições políticas. Ademais, entenderam a necessidade de recuperar o Estado como categoria analítica e como ente indispensável de protagonismo distributivo e agência de reconhecimento de direito civis, culturais e sociais (Domingues, 2013; Leão Rego e Pinzani, 2013; Weyland, Madrid e Hunter, 2010).

Ao longo dos anos 1990, ocorreu uma "nacionalização" do PT, que se afastou do "refundacionismo" de seus primeiros anos e passou a se aceitar como um partido reformador da realidade brasileira. Na passagem da década de 1980 para a seguinte, observou-se um declínio da militância de base e sua substituição por uma militância "profissionalizada". Reconhecendo que a realidade havia se transformado, o I Congresso do PT, em 1991, elaborou estratégia que procurava ampliar o espaço para a luta institucional, uma vez que o movimento social entrara em descenso. Com o tempo, o PT acabou se inserindo na tradição brasileira e latino-americana de projetos políticos pouco nítidos e de amplas coalizões, aglutinando forças com elementos díspares. Nesse sentido, acentuou-se a necessidade, vivida há um século pela social-democracia europeia, de aproximar-se do centro para poder vencer eleiçóes e governar, diluindo sua 
identidade classista e de esquerda (Domingues, 2013; Nobre, 2013; Przeworski, 1989; Silva, 2011; Singer, 2012).

As transformações do PT passaram por uma síntese contraditória daquilo que André Singer (2012) chamou de as "duas almas" do partido: o "espírito do Sion", da época de sua fundação, e a "alma do Anhembi", expressa no programa de governo de 2002 e na Carta ao Povo Brasileiro. Com essas mudanças, a luta de classes foi substituída por um projeto nacional-popular que não era incompatível com os interesses do capital. Na referida carta, Lula assumiu o compromisso com o setor financeiro de manter a orientação econômica do seu predecessor. No entanto, o PT nunca reviu suas posições históricas. Não houve um Bad Godesberg, ${ }^{15}$ nem ocorreu algo como a exclusão da famosa cláusula 4, momento em que o Partido Trabalhista britânico, liderado por Tony Blair, abdicou da socialização dos meios de produção. Nos documentos elaborados em encontros e congressos após a chegada ao poder, o PT continuou mencionando o socialismo (Singer, 2012; Weyland, Madrid e Hunter, 2010).

$\mathrm{O}$ advento da "segunda alma" do PT coincidiu com o surgimento do lulismo, que significou uma orientação baseada na arbitragem pelo alto de interesses conflitantes. A partir de 2003, houve a adoção de políticas para reduzir a pobreza e ativar o mercado interno, sem confronto com o capital. A fortuna da conjuntura internacional associada à virtù de apostar na redução da pobreza produziu o suporte material do lulismo. Isso provocou um realinhamento eleitoral e uma mudança na base social do PT, cristalizada a partir de 2006, com o afastamento da classe média e a adesão em bloco do subproletariado a Lula. Nos anos 1970, Paul Singer havia incluído, nessa fração de classe, os empregados domésticos, os assalariados de pequenos produtores diretos e os trabalhadores

15 O Programa de Bad Godesberg, de 1959, representou a ruptura mais decisiva do SPD com o marxismo. Pela primeira vez, o partido deixava de fora qualquer menção a Marx e à proposta de socialização da indústria de base (Przeworski, 1989; Singer, 2012). 
destituídos das condições mínimas de participação na luta de classes. As decisões tomadas por Lula no primeiro mandato, intensificadas no segundo, foram responsáveis por canalizar as condições favoráveis da economia internacional para a ampliação das políticas sociais em favor das camadas populares. Assim, o lulismo aproveitou-se da onda de expansão mundial e optou por um caminho intermediário ao neoliberalismo da década anterior e ao reformismo forte que havia sido o programa do PT até sua chegada ao poder (Singer, 2012). ${ }^{16}$

A aliança lulista conseguiu convencer a parcela organizada de esquerda da sociedade brasileira de que o ritmo e a velocidade das transformações que estavam imprimindo eram os limites máximos dentro da correlação de forças existente. Para Nobre (2013), o lulismo significou uma ocupação pela esquerda do pemedebismo, envolvendo um pacto com o sistema político em troca de avanço na diminuição das desigualdades sociais. Isso teria tornado o sistema monopolar, no qual "situação" e "oposição" se constituiriam no interior da própria base governista. Essa oposição passiva seria típica de uma pemedebização mais geral da política, em que não haveria polarizações definidas, mas apenas uma cultura comum indistinta. No entanto, Domingues (2013) considera que Nobre minimiza a correlação social de forças que levou Lula a negociar com o PMDB um acordo de governabilidade e buscar capturar o centro do sistema político e da política em geral. Por sua vez, Singer (2012) refuta a hipótese do fim da polarização e argumenta que o lulismo operou uma rearticulação ideológica, retirando a centralidade do conflito entre direita e esquerda e recuperando a gramática varguista que

\footnotetext{
${ }^{16}$ O lulismo significou renunciar a reformas estruturais como a agrária, a urbana e a tributária, por meio da taxação das grandes fortunas, da herança e dos ganhos de capital. É inegável que o PT realizou um antigo ponto programático ao criar um mercado de consumo de massas. No entanto, como adverte José Maurício Domingues (2013), o reformismo fraco está condenado a criar um sistema dual de bem-estar, mercantilizado para os ricos e remediados, residual e na prática formal ou informalmente focalizado para os pobres, ao estilo estadunidense, após o New Deal rooseveltiano perder força em fins dos anos 1930 nos Estados Unidos.
} 
opunha pobres a ricos. Assim, a velha noção de que o conflito entre um Estado popular e elites antipovo se sobrepõe a todos os demais caiu como uma luva para um período em que a polaridade esquerda/ direita foi deslocada para um segundo plano.

Alguns críticos afirmam que o lulismo despolitizou a questão da pobreza e da desigualdade, transformando-as em problemas de administração. Segundo Francisco de Oliveira (2010), no governo Lula, houve a construção de uma "hegemonia às avessas", como na África do Sul pós-apartheid, com a transformação do consentimento em seu avesso: não são mais os dominados que consentem em sua própria exploração; são os dominantes - os setores ligados ao capital - que consentem em ser politicamente conduzidos pelos dominados, desde que a "direção moral" não questione a forma da exploração capitalista. Nesse sentido, Carlos Nelson Coutinho (2010) constata que se foi o tempo em que as batalhas hegemônicas envolviam o enfrentamento de grandes projetos de sociedade. Para ele, hoje predomina a hegemonia da pequena política, baseada no consenso passivo, na aceitação resignada da realidade, na transformação das ideias e dos valores das classes dominantes em senso comum das grandes massas, inclusive das classes subalternas. Há hegemonia da pequena política quando se torna senso comum a ideia de que a política não passa da disputa pelo poder entre suas diferentes elites, que convergem na aceitação do existente como algo "natural".

No plano das políticas sociais, o governo Lula aprofundou o modelo social inscrito na Constituição de 1988 e operou uma articulação entre a política macroeconômica e os programas sociais, combinando crescimento com distribuição de renda. No segundo mandato de Lula, a agenda social-desenvolvimentista ganhou contornos mais nítidos, quando a questão distributiva e as desigualdades - de renda, de poder, de reconhecimento social - passaram para o centro da arena política como ponto de disputa fundamental. A expansão dos programas de transferência de renda - com a criação 
do Ministério do Desenvolvimento Social (MDS) e do Programa Bolsa Família (PBF), em 2003 -, a extensão do financiamento popular via crédito consignado, e a valorização do salário mínimo a partir de 2005 contribuíram para o alívio da situação dos mais pobres e para o surgimento de um mercado interno de massa. No primeiro governo Dilma, nenhum investimento social sofreu cortes orçamentários. Os grandes programas sociais - o Minha Casa, Minha Vida e o Brasil sem Miséria - não só não foram afetados como também registraram expansão significativa (Kauchakje, 2014; Kerstenetzky, 2014; Nobre, 2013; Singer, 2012).

$\mathrm{O}$ PBF, considerado uma referência internacional, rompeu com a lógica fragmentária das políticas sociais e inovou com a criação do cadastro único de beneficiários. Na realidade, o PBF significou mais do que a unificação dos programas até então existentes (Bolsa Alimentação, Bolsa Escola, Vale Gás), pois representou um salto qualitativo, mais do que meramente quantitativo, em relação às políticas públicas dos governos anteriores. $\mathrm{O}$ Bolsa Família foi aos poucos convertido em uma espécie de renda mínima para as famílias que comprovassem situação de extrema necessidade. Entre 2003 e 2006, o programa teve seu orçamento multiplicado por treze, pulando de $\mathrm{R} \$ 570$ milhões para $\mathrm{R} \$ 7,5$ bilhões, alcançando 11,4 milhões de famílias com apenas $0,5 \%$ do PIB. As políticas de transferência de renda contribuíram para a redução da taxa de pobreza absoluta em 36\%, entre 2003 e 2008. Em outubro de 2014, 13,9 milhões de famílias recebiam benefícios do programa com valor médio de R\$ 169,67 (Brasil, 2014; Kauchakje, 2014; Kerstenetzky, 2014; Leão Rego e Pinzani, 2013; Singer, 2012; Weyland, Madrid e Hunter, 2010).

Antes do governo Lula, falar em fortalecimento do mercado interno parecia algo disparatado, pois o pensamento dominante alegava que o aumento do salário mínimo provocaria inflação, desemprego e a quebra da Previdência. Entre 2004 e 2010, registrou-se um crescimento de $10,3 \%$ da participação dos salários na renda 
nacional, enquanto a renda da propriedade decresceu $12,8 \%$. No primeiro decênio deste século, ocorreu a maior expansão quantitativa de ocupações dos últimos quarenta anos. Na sua maioria, os postos de trabalho criados concentraram-se no setor de serviços e na base da pirâmide social, uma vez que $95 \%$ das vagas abertas tinham remuneração mensal de até 1,5 salário mínimo. Daí a importância da política de valorização do salário mínimo, iniciada em 2005 e com previsão para continuar até 2023, cujos impactos distributivos foram ainda mais intensos do que o Bolsa Família. Entre maio de 2004 e janeiro de 2015, o salário mínimo teve um aumento real de aproximadamente $72 \% .{ }^{17}$ Os aumentos do salário mínimo influenciam os rendimentos de assalariados sem carteira e dos trabalhadores autônomos, além de impactar o valor dos benefícios da Seguridade Social. Isso contribuiu para que o índice de Gini, que mede a desigualdade de renda - praticamente estagnado no governo Fernando Henrique, indo de 0,59, em 1995, para 0,58, em 2002 -, caísse de 0,58 para 0,53 entre 2003 e 2010 (Departamento Intersindical de Estatística e Estudos Socioeconômicos, 2014; Nobre, 2013; Pochmann, 2012; Singer, 2012).

No âmbito das forças sociais, a aliança lulista tem se apoiado em uma "coalizão produtivista", envolvendo trabalhadores e setores empresariais. Essa frente neodesenvolvimentista teria como programa a diminuição da taxa de juros, uma taxa de câmbio competitiva e a elevação dos investimentos em infraestrutura. Por um lado, o sindicalismo operário organizado, especialmente a Central Única dos Trabalhadores (CUT), fornece um pilar organizativo e político ao governo, que conta ainda com o apoio eleitoral do subproletariado emergente; a esses setores se agregam a pequena

\footnotetext{
${ }_{17}$ Segundo Singer (2012), a política de valorização do mínimo da era lulista permite uma comparação entre os reformismos fraco e forte. O reformismo forte de Salvador Allende, no Chile, fez no primeiro ano de governo da Unidade Popular o que o reformismo fraco brasileiro levou dez anos para conseguir, pois Allende elevou o salário mínimo em 67\%, em 1971.
} 
burguesia empobrecida e os trabalhadores rurais. Por outro, a aliança com o empresariado nacional foi progressivamente se firmando, sobretudo com a entrada definitiva do PMDB no governo. Entre os setores empresariais que integram o pacto neodesenvolvimentista, destacam-se as grandes empreiteiras, as indústrias de processamento de commodities, as mineradoras, o setor de construção naval e segmentos do agronegócio. Nesse último caso, o boom de commodities teve grande influência na adesão, que continuou se ampliando no governo Dilma, momento em que se alinharam ao pacto até mesmo lideranças ruralistas tradicionais ligadas à Confederação da Agricultura e Pecuária do Brasil (CNA) (Boito e Berringer, 2014; Domingues, 2013; Nobre, 2013; Singer, 2012).

Em oposição ao projeto neodesenvolvimentista, encontra-se a coalizão de interesses rentistas, liderada pelo capital financeiro nacional e internacional, e conta ainda com apoio da grande mídia e da classe média tradicional, que atua como o suporte de massa dessa aliança. Esses setores resistem a propostas de redução da taxa de juros e de controle de capitais. Todavia, alguns analistas apontam para as contradições da própria "coalizão produtivista", em questôes como a reforma tributária, por exemplo, que levou a FIESP a lutar pela derrubada da Contribuição Provisória sobre Movimentação Financeira (CPMF), em 2007. Além disso, a separação clássica entre as esferas produtiva e financeira praticamente não existe. No passado, Lênin já havia destacado a impossibilidade de separar, sob o capitalismo, os investimentos "produtivos" dos "especulativos". Na atual conjuntura, os grandes grupos industriais se financeirizam com o aumento dos ganhos financeiros em relação aos ganhos operacionais (Domingues, 2013; Lênin, 2012; Paulani, 2008; Singer, 2012; Weyland, Madrid e Hunter, 2010). Como afirma Leda Paulani (2008, p. 48),

[...] as críticas em uníssono que os empresários ligados ao grande capital entoam contra os juros elevados fazem parte do jogo de cena de quem tem a obrigação política de se dizer preocupado com os 
milhões de desempregados. As relações que ligam o grande capital produtivo e financeiro, de um lado, e o Estado na posição de emissor de capital fictício, de outro, mostram, no entanto, que esse incômodo não existe, a não ser para os microempresários, os donos de botequins e os proprietários de fabriquetas de fundo de quintal, condenados à "economia de mercado" e à geração de renda real. Em outras palavras, as lógicas produtiva e fictício-financeira é que são, no agregado, conflituosas, não os capitais que delas se beneficiam. ${ }^{18}$

A fim de consolidar a aliança com setores da grande burguesia interna, o governo Lula optou por um modelo de escolher "campeões nacionais" que recebem recursos e apoio para se estabelecer como plataformas de fornecimento - sobretudo de matérias primas - para a economia mundial, controlando a abertura econômica de maneira que se protegesse a indústria instalada no território nacional. Trata-se de uma política neodesenvolvimentista que induz a criação de grandes conglomerados transnacionais baseados no país, empresas que devem ser capazes de integrar as cadeias produtivas ligadas à gangorra sino-americana e de exportar serviços e produtos a países da América Latina e da África. Nesse sentido, a política externa tem funcionado como um importante instrumento para fortalecer setores do grande capital nacional, que necessitam do apoio do Estado para a abertura de novos mercados e para o financiamento, via BNDES, da exportação de bens, capitais e serviços brasileiros (Boito e Berringer, 2014; Nobre, 2013).

O desempenho da coalizão neodesenvolvimentista tem sido afetado pela conjuntura internacional e por disputas internas em seu

\footnotetext{
${ }^{18}$ Esta passagem remete à famosa tripartição estabelecida por Braudel entre vida material, economia de mercado e economia capitalista. Segundo o historiador, o capitalismo não abrange toda a economia, toda a sociedade que trabalha. $\mathrm{O}$ capitalismo de alto voo flutua sobre a dupla espessura subjacente da vida material e da economia de mercado. Trata-se da zona do antimercado, do alto lucro, onde circulam os grandes predadores e vigora a lei da selva. A última camada é o verdadeiro lar do capitalismo (Arrighi, 1996; Braudel, 1987).
} 
interior. A conjuntura internacional favorável é parte da justificativa de que tenha sido possível acelerar a economia e fazer concessões ao capital financeiro ao mesmo tempo, evitando, portanto, o confronto político. ${ }^{19}$ No primeiro governo Lula, combinou-se uma política econômica ultraortodoxa com a expansão da rede de proteção social. No segundo mandato, Lula avançou em uma agenda própria, distinta da de Fernando Henrique. Com a crise de 2008, o Estado e os bancos públicos recuperaram uma capacidade de indução da atividade econômica perdida desde o fim dos anos 1970. No entanto, o governo Dilma coincidiu com o recrudescimento da crise internacional e com os limites das políticas de estímulo ao consumo e de elevação do salário mínimo sem aumento de produtividade. Em seu primeiro mandato, Dilma fez uma inflexão na política econômica, flexibilizando o sistema de metas de inflação e reduzindo os juros (Domingues, 2013; Nobre, 2013; Singer, 2012), no entanto, não houve o esperado aumento dos investimentos privados. $\mathrm{O}$ modelo em que todos ganhavam pareceu ter se esgotado. Assim, é possível que, no atual cenário, ocorram disputas distributivas acirradas no interior da "coalizão produtivista" e em toda a sociedade.

Contra todos os prognósticos dos economistas conservadores, o governo Lula conciliou crescimento com distribuição de renda. As taxas médias de crescimento da economia no período 2003-10 foram praticamente o dobro das alcançadas pelo governo Fernando Henrique. No entanto, com a crise internacional e a queda nos preços das commodities, ficou difícil manter um modelo em que

${ }_{19}$ No período 2002-06, as commodities tiveram valorização média de $89 \%$, com a expansão econômica mundial, pulando de 2,8\%, em 2002, para 5,1\%, em 2006. Nesse período, a balança comercial brasileira tornou-se superavitária, multiplicando por mais de três seu saldo positivo, que passou de US\$13,2 bilhões para US\$ 46,4 bilhões. A partir de 2007, o saldo da balança comercial começou a cair. Já o saldo das contas externas (transações correntes), que havia sido superavitário no período 2004-06 (US\$ 13 bilhões), passou a apresentar elevados déficits após a crise de 2008: déficit de US\$ 28 bilhões em 2008, US\$ 48 bilhões em 2010 e de US\$ 53 bilhões em 2011 (Gonçalves, 2013; Singer, 2012). 
todos os setores da sociedade ganhavam. Com efeito, o governo Dilma atingiu taxas mais baixas de crescimento e assistiu à volta do conflito social, que tende a se acirrar no segundo mandato. $\mathrm{Na}$ tabela 5, é possível verificar as taxas médias de crescimento do PIB entre 1995 e 2014.

Tabela 5 - Brasil: taxas médias de crescimento do PIB nos Governos Fernando Henrique, Lula e Dilma (1995-2014)

\begin{tabular}{lcc}
\hline Governo & Período & Média (\%) \\
\hline \multirow{2}{*}{ Fernando Henrique } & $1995-2002$ & 3,2 \\
& $1995-98$ & 3,4 \\
& $1999-2002$ & 3,1 \\
Lula & $2003-10$ & 4,8 \\
& $2003-06$ & 3,6 \\
Dilma & $2007-10$ & 6,0 \\
\hline
\end{tabular}

Fonte: FMI, 2015.

A estratégia do governo Lula envolveu três pilares: a revalorização do papel indutor e coordenador do Estado, a agenda de inclusão social com a criação de um expressivo mercado de massas e a reconfiguração da política externa como um dos instrumentos-chave da estratégia de desenvolvimento do país. Até aqui foram abordados os dois primeiros pilares. No restante da seção, procurar-se-á destacar as principais contribuições de uma política externa mais ativista e nacionalista, que conseguiu estabelecer um papel mais influente para o Brasil no mundo e na região. Trata-se de uma política externa que enfatizou os aspectos políticos da conduta diplomática e defendeu de maneira mais incisiva os interesses nacionais nos fóruns multilaterais, contribuindo para impulsionar uma nova geografia política e econômica mundial. 
O governo Lula devolveu ao Itamaraty a posição estratégica na formulação e na implementação da política exterior. Para isso, promoveu um amplo redimensionamento do MRE, com a ampliação do número de diplomatas, a abertura de numerosas embaixadas na Ásia e na África (somente nesse último continente foram abertas 19 novas embaixadas) e uma maior abertura da diplomacia à sociedade civil è̀ academia. Um dos traços mais inovadores do governo foi vincular o novo acervo de políticas sociais no plano doméstico a uma ativa diplomacia presidencial. Nesse sentido, as políticas sociais do governo Lula foram ao encontro da agenda que busca corrigir as desigualdades criadas pela globalização neoliberal. Como consequência dessa inovação, muitos programas sociais exitosos foram internacionalizados para países latino-americanos e africanos (Garcia, 2013; Hirst, Lima e Vieira, 2012; Visentini, 2013).

A política externa do governo Lula retomou algumas diretrizes da PEI e do Pragmatismo Responsável, como reafirmar a autonomia ante as grandes potências e ampliar os laços com países em desenvolvimento. Retomou inclusive o vínculo interno/externo que caracterizou a PEI, ao incorporar os trabalhadores à coalizão política do governo e introduzir uma dimensão social na política exterior. Em relação aos países centrais, a política externa brasileira procurou implementar uma agenda internacional própria, independentemente da orientação dos países ricos; uma política revisionista moderada que buscou contribuir para uma nova configuração do poder mundial, sem confrontar os Estados Unidos. Em relação aos países em desenvolvimento, apesar de Fernando Henrique ter se dedicado ao diálogo com alguns Estados, a formação de coalizões Sul-Sul somente foi institucionalizada no governo Lula. Assim, a ideia de autonomia que orientou a política externa dos governos Lula e Dilma procurou influenciar os regimes internacionais por meio de coalizões de geometria variável para contrabalançar a agenda das nações desenvolvidas. 
Desde os anos 1970, observa-se um crescente processo de diferenciação dos países do Sul, acentuado pela crise do petróleo de 1973 e pela ascensão de alguns países periféricos, sobretudo no Leste Asiático. O forte componente idealista do MNA ou do G-77 passou a sofrer com a grande heterogeneidade econômica e política dos seus integrantes, criando problemas de coordenação da ação coletiva. Apesar de a divisão Norte-Sul ainda ser uma característica predominante das relações internacionais do século XXI, as motivações ideológicas do passado não são mais elementos constituintes das aspirações dos países mais importantes do Sul. A diversidade das relações entre esses países, uma consequência da crescente assimetria entre eles, levou à formação de um novo nível secundário de economias emergentes, situado entre as potências tradicionais e o restante do antigo Terceiro Mundo. De certa forma, as chamadas potências médias do Sul, como a África do Sul, o Brasil e a Índia, possuem interesses, influência e capacidade de negociação que as aproxima mais do mundo industrial avançado do que do "velho Sul” (Fonseca Jr., 2004; Hirst, Lima e Vieira, 2012; Lima, 2010; Vieira e Aladen, 2012).

Após um período prolongado de euforia liberal e das tentativas anglo-americanas e europeias de suprimir o pensamento clássico do Sul, que levou a um regionalismo direcionado ao mercado, países importantes do mundo em desenvolvimento passaram a demonstrar uma atitude mais ativista diante do mundo desenvolvido, introduzindo demandas sobre comércio internacional, desenvolvimento econômico e reforma das organizações multilaterais. No contexto de uma "nova onda de politização", alguns poderes emergentes do Sul procuraram coordenar suas políticas externas e adotar novos modelos institucionais para a ação coletiva, como o IBAS, o BRICS, o G-20 financeiro e o G-20 comercial (Vieira e Aladen, 2012).

O IBAS, ou G-3, formalizado com a Declaração de Brasília em junho de 2003, constitui um dos mais importantes esforços cooperativos do Sul no mundo pós-Guerra Fria. Apesar de alguns 
críticos considerarem a coalizão uma forma tardia de terceiro-mundismo, o IBAS representa um foro de coordenação política sobre diferentes temas, visto que há significativas sinergias entre os três países, pois desenvolveram capacidades específicas em distintos setores ao longo de décadas. Trata-se de uma iniciativa que é ao mesmo tempo um arranjo cooperativo, envolvendo a troca de bens materiais, simbólicos e ideacionais, e uma coalizão, pois implica a articulação de posições comuns em arenas regionais e globais. Dos três eixos principais do Fórum, dois exemplificam o conceito de arranjo cooperativo: a cooperação entre seus membros em intercâmbios técnicos e a cooperação trilateral com países de menor desenvolvimento relativo. $\mathrm{O}$ terceiro pilar está mais próximo do conceito de coalizão, na medida em que significa a coordenação de posições comuns no plano multilateral (Lima, 2010; Visentini, 2013).

A coordenação política de posições comuns no plano internacional envolve demandas pela reforma das instituições de governança global - em especial do CSNU -, ademais da cooperação trilateral Sul-Sul no campo da defesa, com as manobras navais das três marinhas, denominadas IBAS-Mar. Além da visão geopolítica, os países do IBAS conferem importância fundamental a questões de cunho social e humanitário. No plano da cooperação para o desenvolvimento, a constituição do Fundo IBAS de Combate à Fome e à Pobreza em 2004 é responsável pelo financiamento de projetos em países de menor desenvolvimento relativo, como Burundi, Guiné-Bissau, Haiti e Palestina. De modo geral, o modelo de cooperação do IBAS se apresenta como um instrumento idealizado por potências médias que poderia contribuir para a configuração de uma ordem mundial multipolar (Amorim, 2013; Hirst, Lima e Vieira, 2012; Lima, 2010).

Inicialmente um acrônimo cunhado pelo economista do Goldman Sachs Jim O' Neill em 2001, o BRICS transformara-se em uma real e consistente articulação portadora de novas propostas para enfrentar os desafios de um sistema internacional em transformação, 
sobretudo após a crise de 2008. Entre 2003 e 2010, o crescimento dos países do grupo representou cerca de $40 \%$ da expansão do PIB mundial. No mesmo período, registrou-se aumento de $575 \%$ na corrente de comércio entre o Brasil e os membros do BRICS, com as trocas comerciais passando de US\$10,71 bilhões para US\$ 72,23 bilhões. No plano estratégico, os países que compõem o BRICS - Brasil, Rússia, Índia, China e África do Sul - têm defendido concepções de ordem internacional que desafiam as do Ocidente liberal, conquanto as diferentes trajetórias e capacidades estatais limitem o revisionismo de alguns de seus integrantes. Por sua situação geopolítica, situado na área imediata de projeção político-militar dos Estados Unidos, o Brasil possui menor alcance na sua projeção internacional de poder (Garcia, 2013; Hurrell, 2009a; Lima, 2010; Visentini, 2013). No entanto, isso não impediu a política externa brasileira de adotar iniciativas ousadas, como convidar os doze chefes de Estado sul-americanos integrantes da Unasul para participar da VI Cúpula do BRICS, realizada em Fortaleza, em julho de 2014.

O diálogo político do BRICS, iniciado de forma ad hoc

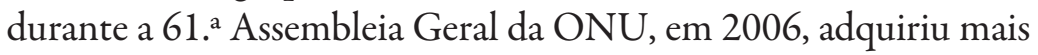
institucionalidade com as cúpulas de chefes de Estado iniciadas em 2009. Nessas reuniões, foram discutidos temas como a recuperação da economia global, a reforma do sistema multilateral e a criação de instituições próprias. Na cúpula de Fortaleza, o BRICS aprovou um acordo para criar duas instituições financeiras multilaterais, o Banco de Desenvolvimento (New Development Bank, NDB) e o Fundo de Reservas (Contingency Reserve Arrangement, CRA). Caso venham a funcionar e a gerar o impacto esperado, essas instituições poderão significar a mais importante inovação financeira multilateral desde Bretton Woods, embora, como afirmou a presidenta Dilma, as novas entidades não estejam em oposição ao FMI e ao Banco Mundial. O novo Banco de Desenvolvimento contaria com um capital de US\$ 100 bilhões e seria criado com o objetivo de mobilizar recursos para financiar projetos de infraestrutura e desenvolvimento sustentável 
para seus membros e demais países emergentes. Já o Fundo de Reservas atuaria como mecanismo preventivo e de apoio à liquidez do balanço de pagamentos das cinco economias do BRICS, contribuindo para enfrentar a volatilidade e promover a estabilidade financeira. Assim, a criação das novas instituições constitui uma apropriação mais autônoma do futuro, além de uma externalidade positiva para a economia global (Bárcena, 2014; Visentini, 2013).

Durante a crise de 2008, o Brasil percebeu o surgimento de uma oportunidade para alterar a estrutura do sistema financeiro internacional. Desde então, o país busca contribuir para a afirmação de arranjos multilaterais informais, como o G-20 financeiro, criado após a crise asiática em 1999. A substituição parcial do G-8 pelo G-20 como foro privilegiado de interlocução dos líderes mundiais simbolizou uma mudança significativa na configuração dos arranjos de governança internacional. $\mathrm{O}$ reconhecimento da legitimidade do G-20 levou à sugestão de reforma do FMI e do Banco Mundial, com o aumento do poder decisório do BRICS nessas instituições, e à decisão de injetar US\$1,1 trilhão para a recuperação da economia internacional, montante que contou com a contribuição de Brasil, China e Rússia. Dessa forma, nos encontros após a crise, tornou-se patente a insuficiência do G-8 e a importância crescente do BRICS na reestruturação e na estabilização da economia mundial (Lima, 2010; Vigevani e Ramanzini Júnior, 2013).

Nas negociações comerciais, a estratégia do governo Lula envolveu três linhas de mudanças em relação ao governo anterior. Em primeiro lugar, as negociações preferenciais com os países do Norte perderam peso. Com a retomada da agenda de desenvolvimento no plano internacional, a política externa brasileira intensificou as críticas à incoerência entre o discurso liberalizante e a prática protecionista das economias desenvolvidas. Ademais, o governo entendeu que era possível manter boas relações com os países ricos sem as concessões que resultariam de acordos amplos de abertura de mercados, muitas vezes assimétricos. Em segundo lugar, a partir 
de 2003 adquiriram relevância, na estratégia do Brasil, as negociações com outros países em desenvolvimento, com a reativação da dimensão Sul-Sul. No entanto, o surgimento do G-20 comercial rompeu com o posicionamento das coalizões do tipo bloco, como o G-77, que se pautava por uma agenda defensiva. A nova coalizão, que reintroduziu a dimensão Norte-Sul nas negociações agrícolas, passou a adotar uma agenda demandante, proativa, e não de veto como no passado. Por fim, a estratégia do governo Lula incluía a adoção de uma postura ofensiva e propositiva na defesa dos interesses do competitivo agronegócio brasileiro (Campos, 2012; Motta Veiga, 2007; Parola, 2007; Vigevani e Cepaluni, 2011).

As três inflexões introduzidas pelo governo Lula conduziram a estratégia de negociações comerciais de volta aos trilhos da tradição nacional-desenvolvimentista da política externa brasileira. Reverteu-se o movimento do governo anterior de "autonomização" das negociações comerciais em relação aos objetivos mais gerais da política externa. Em 2003, o Brasil liderou a formação do G-20, que conferiu um caráter Norte-Sul às negociações agrícolas e projetou o país como líder de uma coalizão heterogênea formada por nações com posturas divergentes em relação à liberalização agrícola. O G-20 teve a capacidade de colocar juntos grandes exportadores - como Brasil e Argentina -, importadores líquidos de alimentos - como Egito e Paquistão -, e países em busca de autossuficiência - como a Índia (Campos, 2012; Lima, 2010; Motta Veiga, 2007).

A origem do G-20 revela um equilíbrio entre a lógica comercial e a preocupação sistêmica. Sua atuação foi um dos fatores decisivos para impedir que os Estados Unidos e a UE reeditassem, em Cancún, o caráter anacrônico e antidemocrático da dinâmica negociadora bipolar das rodadas anteriores. O Grupo surgiu como uma reação à proposta conjunta de norte-americanos e europeus, que ameaçava reduzir a abrangência da Rodada Doha em questões agrícolas e se encontrava em contradição com a "Agenda do Desenvolvimento", adotada no início das negociações. Nesse sentido, o G-20 mostrou que 
a coordenação Sul-Sul não era um objetivo hipotético ou irrealista, visto que se movia por motivações legítimas, baseadas no conhecimento técnico e em propostas concretas. Além disso, reforçou o IBAS e o Mercosul como interlocutores nesse e em outros foros multilaterais (Campos, 2012; Lima, 2010; Parola, 2007).

No âmbito regional, o governo Lula conferiu clara prioridade à América do Sul ao traçar a estratégia de inserção internacional do Brasil. A importância atribuída à integração regional foi também facilitada pela crise de liderança dos Estados Unidos na região no início do século XXI. Ademais, foi reforçada pelos laços históricos que uniam o PT a outros partidos progressistas que também chegaram ao poder no mesmo período. Diante da disjuntiva de se inserir isoladamente ou em conjunto com os demais vizinhos, os governos Lula e Dilma compreenderam o papel que uma América do Sul unida poderia desempenhar em um mundo multipolar em formação. Assim, a perspectiva de um futuro compartilhado incentivou a ideia de autonomia e a construção conjunta de uma agenda sul-americana.

Diferentemente do governo Fernando Henrique, que concebia a integração nos marcos do regionalismo aberto como plataforma para o fortalecimento da inserção competitiva do Brasil na economia mundial, o governo Lula procurou fortalecer a região economicamente, socialmente e politicamente. A inserção soberana do Brasil devia passar pela unidade da América do Sul, concebida como um importante ator geopolítico e estratégico na cambiante ordem internacional (Dulci, 2013; Lima e Duarte, 2013). Para isso, seria preciso impedir a criação da Alca, fortalecer o Mercosul e criar instituições de articulação política, como a Unasul.

Em relação à Alca, o governo Lula se opunha ao projeto norte-americano, baseado em um modelo único e com regras homogêneas para a região como um todo. Essa oposição foi marcada mais por questões pontuais da agenda do que por objeções ideológicas, apesar de o governo reconhecer o caráter político da proposta. $\mathrm{O}$ 
ministro Celso Amorim propôs que temas normativos complexos, como subsídios agrícolas, investimentos, serviços e propriedade intelectual deveriam ser tratados no plano multilateral, e não no nível hemisférico. A ideia de uma Alca mais equilibrada, contudo, sofreu forte oposição de setores burocráticos (MDIC e Ministério da Agricultura) e econômicos (agronegócio, sucroalcooleiro), defensores do acordo original. $\mathrm{O}$ contexto de alta politização, envolvendo os governos de esquerda da região e o protecionismo estadunidense, levou ao naufrágio da Alca na IV reunião da Cúpula das Américas, em 2005 (Amorim, 2013; Hirst, 2009).

O fracasso da Alca colocou em evidência as divergências ideológicas em matéria de política externa entre PT e PSDB. Como visto na seção 2.2, o PT sempre se opôs à proposta, considerada uma forma de anexação, e, uma vez no poder, o governo Lula contribuiu para barrar sua concretização. Confirmando a polarização partidária sobre o tema, o ex-chanceler Luiz Felipe Lampreia (2010) acredita que a Alca foi uma oportunidade perdida, cujo fracasso levou à proliferação de acordos de livre comércio no continente que excluem o Brasil. Na mesma direção, Cardoso (2010) considera que o colapso das negociações restringiu as opções brasileiras, isolando o país no Mercosul.

Em relação ao Mercosul, o projeto foi considerado pelo governo Lula como o núcleo principal em torno do qual tende a se consolidar a integração sul-americana. A aproximação entre o Mercosul e a Comunidade Andina de Nações (CAN) e a entrada da Venezuela no bloco sul-americano demonstraram o caráter estratégico do projeto de integração para a política externa brasileira. Desde 2003, a nova administração promoveu uma espécie de relançamento do bloco, o que incrementou sua dimensão comercial, aprofundando sua institucionalidade e, principalmente, dando-lhe maior conteúdo político. Em 2007, o Parlamento do Mercosul (Parlasul) começou a funcionar, substituindo a antiga Comissão Parlamentar Conjunta. Outra decisão importante foi o reconhecimento das assimetrias estruturais intrabloco, tema que não havia sido discutido 
desde o seu surgimento, com o Tratado de Assunção. A criação do Fundo para a Convergência Estrutural do Mercosul (Focem), inicialmente com US\$100 milhões, foi uma importante iniciativa para enfrentar as assimetrias e viabilizar projetos estratégicos nos sócios menores. Em 2010, a carteira do fundo atingiu US\$ 1 bilhão, contribuindo para o financiamento de estradas, linhas de transmissão elétrica, além de iniciativas sociais, como a construção de moradias populares e redes de saneamento básico (Dulci, 2013; Cruz, 2010; Vigevani e Cepaluni, 2011).

Nos últimos anos, começou a ganhar peso no Brasil, sobretudo em setores oposicionistas e em alguns segmentos empresariais, o argumento de que o Mercosul seria um fator limitante da capacidade de diversificação das parcerias do país. As dificuldades enfrentadas pelas economias nacionais, principalmente a argentina, contribuíram para as ressalvas em relação ao bloco. Para setores ligados à CNI e à FIESP, o Mercosul seria uma âncora que atrapalharia o Brasil nas negociações internacionais, dificultando acordos bilaterais com Estados Unidos e UE. Muitos empresários discutem até a possibilidade de converter a atual união aduaneira imperfeita em uma área de livre comércio, em consonância com o que tem sido defendido pelo PSDB nos últimos anos. Em que pese suas limitações, a manutenção do Mercosul parece relevante para a economia brasileira, principalmente para a exportação de bens industrializados. Na defesa do bloco, alguns analistas argumentam que, entre 1990 e 2013, o Brasil só teve déficit em nove anos. Além disso, 90\% das exportações brasileiras para o bloco seriam de bens manufaturados (Cano, 2014; Lima e Duarte, 2013; Vigevani e Cepaluni, 2011).

A importância atribuída à América do Sul pela política externa brasileira culminou na criação de uma instituição política: a Unasul. Trata-se de um fórum de articulação política, um instrumento que confere à região maior autonomia no sistema internacional. A ideia é que no âmbito da Unasul convivam governos de 
distintas posições ideológicas e com diferentes projetos de integração. O papel da diplomacia brasileira foi fundamental para a formação do novo organismo, uma vez que atuou para conciliar posições divergentes entre os países que defendiam apenas uma integração econômico-comercial e aqueles que pleiteavam uma união política. Segundo Amorim (2013), as discussões em torno da criação de uma secretaria para a Unasul provocaram fortes divergências entre os países. Os defensores de uma integração mais fluida, com ênfase no caráter comercial, eram contrários à ideia. Já Venezuela e Equador a defendiam com ardor. A solução foi um compromisso, criando-se uma secretaria destituída dos poderes com que pretendiam dotá-la os bolivarianos. Para o ex-ministro brasileiro, era inconcebível uma dimensão sem a outra. Nesse sentido, o empenho do Brasil logrou criar uma organização que já deu provas de sua relevância como instrumento de solução de diferenças e de projeção da identidade sul-americana. ${ }^{20}$

Após analisar as linhas gerais que estruturam a política brasileira de integração regional, faz-se necessário tratar dos desafios representados pelo processo de desindustrialização brasileira e pela emergência da China como parceira da região. Há alguns anos, o Brasil passa por aquilo que a UNCTAD denominou de "desindustrialização precoce ou negativa", que difere do fenômeno secular de terciarização das economias. Nos países desenvolvidos, a chamada "desindustrialização normal ou positiva" implicou uma tendência de redução dos setores primário e secundário no PIB e de elevação do setor terciário no longo prazo. Já nos países em desenvolvimento, especialmente nos latino-americanos, a "desindustrialização prematura” resultou de um viés de deslocamento

${ }^{20}$ Celso Amorim (2013) chama a atenção para uma pequena discussão sobre o nome do novo organismo, na qual acabou predominando a visão de Hugo Chávez, Unasul, em detrimento da proposta brasileira, Comunidade ou Casa. Apesar de a ideia brasileira ser aparentemente mais aberta ou plural, a palavra Unasul possui uma conotação mais geopolítica e estratégica. 
da fronteira de produção na direção dos produtos intensivos em recursos naturais, fenômeno que costuma ocorrer principalmente nas fases ascendentes dos preços de commodities no mercado mundial. A diminuição da indústria de transformação brasileira como proporção do PIB pode ser verificada na tabela 2. Ademais, a participação do Brasil na produção da indústria de transformação mundial, que era de 2,8\%, em 1980, caiu para $2 \%$, em 1990, e atingiu 1,7\%, em 2010. Entre 2003 e 2010, a taxa de crescimento real do valor adicionado da mineração foi de $5,5 \%$, da agropecuária, 3,2\%, e da indústria de transformação, 2,7\%. Os efeitos sobre a pauta exportadora não tardaram a ocorrer. A participação dos produtos manufaturados no valor das exportações mostrou forte tendência de queda, passando de 56,8\%, em 2002, para 45,6\%, em 2010. No mesmo período, houve clara tendência de aumento da participação dos produtos básicos, que subiram de $25,5 \%$ para 38,5\% (Cano, 2014; Gonçalves, 2013).

Na primeira década do século XXI, a fronteira de produção do Brasil teve viés pró-mineração, pró-agropecuária e anti-indústria de transformação. O processo de ascensão da China como importante parceiro comercial foi um dos principais responsáveis pela aceleração da desindustrialização brasileira, aumentando a vulnerabilidade externa estrutural do país na esfera comercial via maior dependência em relação às commodities, cujos preços são mais sensíveis à conjuntura internacional. As relações bilaterais Brasil-China são um bom exemplo do comércio Sul-Sul, embora tenham um forte caráter Norte-Sul ou centro-periferia, em que o Brasil exporta matérias primas e importa produtos manufaturados. Apesar dos impactos positivos dos termos de troca, já decrescentes, as empresas brasileiras têm sofrido com as pressões competitivas geradas pelas importações chinesas, que causam perda significativa na participação de mercado na regiáo, além dos deslocamentos produzidos no plano doméstico. Mesmo assim, a flagrante carência da infraestrutura brasileira oferece uma oportunidade de parcerias benéficas para 
ambas as partes (Braga e Lehmann, 2014; Gonçalves, 2013; Lima e Duarte, 2013). ${ }^{21}$

O desenho geral da economia brasileira - baixa competitividade, incapacidade de inovação, dependência da exportação de produtos primários - traz sérias interrogações quanto à continuidade do atual padrão de desenvolvimento. A geração de empregos de qualidade, por exemplo, somente será possível com a manutenção e a recuperação da indústria. Ao contrário da China, o Brasil entrou na globalização cedendo em questões fundamentais, como a abertura da conta de capital. Não abrir a conta de capital significa manter o controle sobre a entrada/saída de capitais, as remessas de lucro e os fluxos de investimentos. Mais do que isso, é ter um grau avançado de soberania no manejo de sua política cambial, fiscal e monetária. Para ser bem-sucedida, a política industrial tem de ser consentânea com a política macroeconômica. Com os juros elevados, o câmbio valorizado, o atual nível de abertura econômica e o descontrole da conta de capital, não será possível reverter o quadro de desindustrialização acima analisado (Cano, 2014; Domingues, 2013).

Em suma, a projeção internacional do Brasil nos últimos anos reflete uma diplomacia ativa que questiona a ordem liberal, aprofunda a cooperação Sul-Sul e fortalece a integração sul-americana. Se dependesse de setores da elite regional, a tendência natural era

${ }^{21}$ Um bom exemplo dessas oportunidades são as atividades desenvolvidas pela Sinopec Corporation (China Petroleum \& Chemical Company) em parceria com a Petrobras. A Sinopec foi contratada pela empresa brasileira para desenvolver alguns trechos de seu gasoduto GASENE para gás natural, projeto concluído em 2010 a um custo estimado de US\$ 1,9 bilhão. Mais recentemente, a Sinopec fez um investimento de US\$ 7,1 bilhões na aquisição de uma participação de $40 \%$ na filial brasileira da Repsol, empresa de energia espanhola, e adquiriu direitos de exploração de campos petrolíferos do pré-sal brasileiro (Braga e Lehmann, 2014). Além disso, deve-se destacar que a China estimula reorientações estratégicas e parcerias no setor de tecnologia avançada, envolvendo empresas como a Embraer e o lançamento conjunto de satélites (Vigevani e Cepaluni, 2011). 
que a América do Sul seguisse como uma periferia econômica, em aliança subordinada com os países centrais. A possibilidade de uma alternativa sul-americana mais autônoma e soberana depende cada vez mais das escolhas do Brasil. Como se argumentou ao longo da seção, a consolidação de um projeto integracionista que fomente a integração produtiva, diminua as desigualdades sociais e projete geopoliticamente a região depende de uma coalizão de poder capaz de se contrapor aos setores conservadores e construir uma nova hegemonia no Brasil e na América do Sul.

\subsection{Síntese do capítulo}

Na primeira seção, analisou-se a estreita vinculação entre o projeto nacional-desenvolvimentista e as duas ideias-força que explicam os principais traços de continuidade da política externa brasileira: autonomia e desenvolvimento econômico. Entre 1930 e 1980, contribuir para o desenvolvimento significava industrializar o Brasil. Já o conceito de autonomia implicava aumentar as margens de manobra do país no sistema internacional. Como lembra Gelson Fonseca Jr. (2004, p. 361), “[...] as expressões do que é autonomia variam histórica e espacialmente, variam segundo interesses e posições de poder”. Ao longo da seção, procurou-se demonstrar que o significado concreto dos dois eixos explicativos varia de acordo com o sistema internacional em dado momento e com as coalizões políticas domésticas.

Na segunda seção, destacou-se a atuação dos partidos políticos brasileiros na esfera da política externa, com destaque para polarização entre PSDB e PT. Desde a redemocratização, a política exterior passou a ser mais politizada, apesar de sua escassa repercussão eleitoral. Após uma breve discussão da literatura sobre o assunto, realizou-se um levantamento das propostas de política externa de PSDB e PT nas eleições presidenciais ocorridas entre 1994 e 2014. Os programas eleitorais revelaram as principais diferenças entre os dois partidos, que foram analisadas nas seções seguintes. 
Na terceira seção, analisou-se o governo Fernando Henrique, as reformas neoliberais realizadas e a política externa voltada para a inserção competitiva na economia global. O então presidente liderou uma coalizão envolvendo setores da burguesia, o capital financeiro, a alta classe média e os meios de comunicação; as reformas aumentaram a produtividade e a competitividade da economia, mas ao custo do aumento do desemprego. No âmbito externo, Fernando Henrique procurou restaurar a credibilidade política e econômica do país, por meio da adesão aos regimes internacionais e da adoção de políticas liberais. Buscava-se, assim, obter as credenciais tidas como necessárias para que o Brasil pudesse inserir-se em condições mais favoráveis no cenário global.

$\mathrm{Na}$ quarta seção, foram analisadas as políticas doméstica e externa dos governos Lula e Dilma. Aquele combinou crescimento econômico com distribuição de renda, aproveitando o contexto internacional favorável para ampliar as políticas sociais; crescer e distribuir os frutos do crescimento, agradando parte da elite e os mais pobres, foi o caminho adotado pelo lulismo. Por sua vez, Dilma assumiu em um momento de recrudescimento da crise internacional e de acirramento do conflito distributivo. Os governos progressistas procuraram aprofundar os pilares históricos que informam a diplomacia brasileira, pois a política externa reincorporou os objetivos de desenvolvimento e passou a buscar maior autonomia frente aos Estados Unidos e demais países desenvolvidos. Lula priorizou a política exterior, projetando-se como uma importante liderança mundial. Mesmo mantendo as linhas gerais da política externa de seu antecessor, Dilma não conferiu a mesma prioridade à política externa, sobretudo à sua dimensão regional. Apesar dessas diferenças, Lula e Dilma adotaram uma diplomacia que pretendeu contribuir para uma nova geografia política e econômica mundial. 
No ensaio Balmaceda, Joaquim Nabuco afirma que o valor dos chefes de Estado sul-americanos deveria ser julgado pelo resultado de sua administração, comparando-se a situação em que receberam o país e na qual o deixaram. Apesar das limitações, o saldo do inventário dos 12 anos compreendidos entre 2003 e 2014, quando se articulou uma política externa ativa com uma agenda social inclusiva, foi positivo. 